Discussion Paper No. 14-113

Age and Skill Bias of Trade Liberalisation?

Heterogeneous Employment Effects of EU Eastern Enlargement

Jan Fries

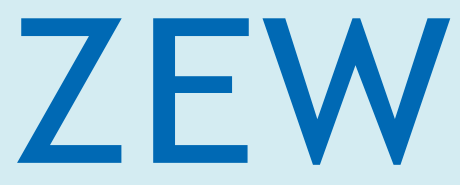

Zentrum für Europäische Wirtschaftsforschung $\mathrm{GmbH}$

Centre for European

Economic Research 
Discussion Paper No. 14-113

\title{
Age and Skill Bias of Trade Liberalisation? Heterogeneous Employment Effects of EU Eastern Enlargement
}

\author{
Jan Fries \\ Download this ZEW Discussion Paper from our ftp server: \\ http://ftp.zew.de/pub/zew-docs/dp/dp14113.pdf
}

Die Discussion Papers dienen einer möglichst schnellen Verbreitung von neueren Forschungsarbeiten des ZEW. Die Beiträge liegen in alleiniger Verantwortung der Autoren und stellen nicht notwendigerweise die Meinung des ZEW dar.

Discussion Papers are intended to make results of ZEW research promptly available to other economists in order to encourage discussion and suggestions for revisions. The authors are solely responsible for the contents which do not necessarily represent the opinion of the ZEW. 


\title{
Age and skill bias of trade liberalisation? Heterogeneous employment effects of EU Eastern Enlargement
}

\author{
Jan Fries *
}

16th December 2014

\begin{abstract}
This study analyses the 2004 Eastern Enlargement to the European Union to obtain evidence on the employment effects of an increase in trade liberalisation. The Enlargement is thought to generate a trade-induced demand shock with no (or only limited) supply effects. Besides the variation over time induced by the Enlargement, identification of the effects is based on a Melitz (2003) type productivity term to differentiate firms by the extent of exposure to the demand shock. The idea is that the effects of the demand shock should be driven by differences in firm-level productivity from the period before the new member countries actually entered the EU. German linked employer-employee data allow to observe the relation of initial establishment productivity with employment changes over a long panel from 1995 to 2009. The estimates show that the Enlargement had a negative effect on establishment-level employment growth, which is driven by increased worker separations and increased job destruction. Besides the overall employment effect, the study focuses on effect heterogeneity across age and skill groups of the workforce. These estimates point to a skill bias in the effect of the Enlargement that disadvantages low- and medium-skilled workers in terms of higher worker separation and job destruction. In addition, lowskilled workers suffer fewer accessions by firms, where against medium-skilled workers enjoy increased accessions and creation of new jobs. Besides this indication for a skill bias, there are no clear indications that point to an age bias in the employment effect of the Eastern Enlargement.
\end{abstract}

Keywords: $\quad$ Market integration, productivity,

JEL classification: J21, J63

\footnotetext{
${ }^{*}$ Centre for European Economic Research (ZEW), PO Box 103443, D-68034 Mannheim, Germany, fries@zew.de. I am grateful to Bernd Fitzenberger, Claudia Fries, Nicole Guertzgen, Jan Hogrefe and Ulrich Zierahn for helpful comments, and to seminar participants in Freiburg and Melbourne for fruitful discussions. Financial support from the Fritz-Thyssen Foundation is gratefully acknowledged.
} 


\section{Introduction}

Globalisation steadily pushes international trade: Goods, services, information and capital move to where they generate the highest return, thereby accelerating dynamics on product and labour markets. In Europe, the progress of the European Union (EU) decisively drives market integration across its member countries. While national product markets interweave increasingly, labour markets are more segmented. But integration of product markets can generate shocks to labour markets, increasing the demand for a flexible labour force. In this study, I analyse the employment effects of a trade-induced demand shock that has been raised by the 2004 Eastern Enlargement to the EU.

The employment consequences of trade liberalisation are discussed controversially. Liberalisation is said to generate overall welfare gains when firms conquer new export markets. Wage inequality increases, but the effect on unemployment can theoretically go in either direction (Egger and Kreickemeier, 2009; Helpman et al., 2010). Consequences for employment seem to depend on the structure of employers and regions. In export-oriented regions, employment increases, where it decreases in regions that experience import pressure (Autor et al., 2013a,c; Dauth et al., 2014). Trade opening can also hurt particular groups or have an undesirable distribution (Slaughter, 1998). When skill and demographic groups are imperfect substitutes in the production process, relative demand shifts between these groups alter employment and wages (Katz and Autor, 1999).

A trade-induced demand shock is likely to shift the relative demand for skills. The classical argument is that trade liberalisation leads to a specialisation in high skills in a country that has a relative abundance of high-skilled workers, so that the demand for low-skilled workers decreases. Recent studies analyse several channels through which lowskilled workers may be affected. First, trade integration shifts production towards more productive firms, of which the most productive export (Melitz, 2003). These firms may produce higher-quality goods, requiring higher-skilled workers, and decreasing demand for lower-skilled workers (Verhoogen, 2008). In this process of skill upgrading, more productive workers select themselves into exporting firms. A second explanation is offshoring of low-skilled jobs to countries with abundance of low-skilled workers (Feenstra and Hanson, 1996). Domestic jobs for low-skilled workers are destroyed, and relative demand goes up for higher-skilled workers. Third, trade can trigger technology upgrading or skill-biased technological change, where the productivity of skilled workers increases through better technology (Bustos, 2011). The adoption of better technology can displace low-skilled jobs and shift relative skill demand upwards.

Technological and organisational change is suspected to be age-biased as well (Aubert et al., 2006; Beckmann, 2007). Demographic change and an ageing workforce are likely to intensify the effects of trade liberalisation. Older workers are a specific group on the labour market, as they face a decision between employment and retirement. They are slower in adapting to new requirements and technologies, and are less likely to catch up with changes on the labour market (Skirbekk, 2008). Empirical studies on age-biased 
technological change denote a discrimination of older over younger workers.

To summarise, the literature indicates that a shock in trade liberalisation has differential effects on workers in different skill and age groups. A trade-induced demand shock is likely to favour higher-skilled over lower-skilled workers, and younger over older workers. To empirically investigate these patterns, I use the 2004 EU Eastern Enlargement as a source of exogenous variation in trade liberalisation to estimate heterogeneous employment effects on the establishment level. The impact of the 2004 Enlargement has been the object of research for a few studies. In an ex-ante study, the Enlargement has been suspected to have undesirable distributional effects (Boeri and Brücker, 2001). The ex-post studies by Braakmann and Vogel $(2010,2011)$ and Brülhart et al. (2012) analyse the effect of the Enlargement on employment and wages in Germany and Austria, respectively. Similar to my analysis, the studies are based on a treatment intensity term to approximate how strong firms and workers are affected by the market integration. But as a measure for the treatment intensity, they use the distance between the region and the border to Poland or the Czech Republic as treatment intensity. Their argument is that firms are affected more strongly the closer they are to the opening market. This seems to be relevant for service firms that operate close to the opening border and profit from an increased customer market. Though, the argumentation that more distance goes along with higher transportation costs for manufactured goods is not completely convincing. While a large part of world trade is operated between neighbour countries, the marginal transport costs of distance are in decline (Hummels, 2007). It is unlikely that the transportation of a specific good on a lorry or a train is much more costly for a Swabian manufacturer over a distance of 350 kilometres than for a firm located in Nuremberg over a distance of 150 kilometres.

Therefore, I refrain from using a distance measure and rely on a Melitz-type productivity term to differentiate manufacturing firms by how strong they are affected. The idea is that the effects of the demand shock induced by the Enlargement should be driven by differences in productivity of German firms before the new member countries actually entered the EU. For this study, I rely on German linked employer-employee data, which enable me to analyse initial establishment productivity. The employee data give precise information on employment outcomes, like worker flows and job flows. Based on this framework, I estimate the effect of the Enlargement on employment growth within establishments, and analyse the heterogeneity over age and skill groups. I find that employment growth drops in reaction to the Enlargement, and this effect seems to be channelled by increased worker separation and increased job destruction. Furthermore, the estimates suggest the effect of trade liberalisation on employment is skill-biased, as low- and medium-skilled workers experience increased worker separation and job destruction as compared to the high-skilled. Besides the indication for a skill bias, the results do not suggest the presence of an age bias that is directed against older workers.

This study is structured as follows. Section 2 introduces the increase in trade liberalisation by the European Union Eastern Enlargement and argues how this change creates quasi-experimental variation that is used by my estimation approach. Section 3 guides 
through the literature and derives hypotheses. The data base and descriptive facts are explained in Section 4. Section 5 presents the empirical model, which is applied to estimate the effect of trade liberalisation on employment changes in Section 5.1, and to estimate heterogeneous effects over age and skill groups in Section 5.2. Section 6 discusses the empirical results and concludes.

\section{The 2004 EU Eastern Enlargement}

Focusing on Europe, globalisation and trade liberalisation find an expression in the European Union. The EU is on a course of accession which will not come to a halt in the near future. Among recent enlargements, the Eastern Enlargement on 1st May 2004 is the largest, when ten new member countries joined simultaneously. On that day, the population of the EU grew from 380 to more than 450 million, and GDP increased by 5 per cent. In the following years from 2004 to 2008, GDP of the new members grew by 23 per cent compared to 8 per cent for the old EU members.

Preceding the accession, the EU already held treaties with all these new member countries. In 1991, the EU started an association process with the Central and Eastern European Countries (CEEC) to economically connect those countries by creating a freetrade area and preparing their potential accession. During the following years until the actual accession of the new member countries, several achievements were made to harmonise trade and economic development. In the exemplary case of Poland, the European Commission stated in July 1997 that certain judicial and free-trade rules were implemented, but that more effort is needed to catch up with the requirements. Several reports by the Commission document progress and regress in the implementation of the common market. So in a process that took more than 12 years, Poland slowly completed the transition to the common market and tariff union of the EU. Within that time span, tariffs and quantity restrictions on imports and exports were completely abolished, but stepwise for different product groups and industrial sectors. The accession of Poland and the 9 other countries was recommended by the European Commission only on 9th October 2002, and the actual decision was made on 13th December 2002. In the course of the year 2003, the accession treaties were ratified by the 10 new member countries. The accession treaty with Poland was finally signed on 16th April 2003.

On the actual date of the Enlargement on 1st May 2004, technical barriers to trade were harmonised and all customs control procedures between the EU and the new member countries were eliminated. Not before this date, every citizen could cross the borders and every firm could trade goods without any customs control procedures and without waiting time. Moreover, these countries were now part of the EU, and harmonisation of standards, subsidies, regulation and national legal frameworks from then on were administered on the supranational level.

Germany had a specific position in the accession of the CEEC. About 50 per cent 
of imports to the new member countries is produced in Germany. ${ }^{1}$ The Enlargement constituted a shock to German product markets by the elimination of borders between partially integrated countries. The treatment in my analysis is the actual opening of the borders, which facilitated direct trade between producers and customers Germany and the new member countries.

In contrast, labour markets were not liberalised at the same time. Free movement of labour for 7 out of the 10 new member countries, namely the Czech Republic, Estonia, Latvia, Lithuania, Poland, Slovenia and Slowakia, to Germany was delayed 7 years after the accession date. This to some extent excludes supply effects in terms of labour movement from the new member states to occur simultaneously with the liberalisation of trade flows.

The actual accession of these countries caused a significant rise in product-specific trade. The analysis by Hornok (2010) shows that the 2004 accession increased bilateral exports of manufactured products in country relations of a former member country with at least one new member country by 15 per cent. Besides rising export opportunities for firms in the pre-Enlargement EU, there is evidence for increased import competition from newly accessed member countries. Consequently, recent studies document increases in German imports and exports (e.g. Baas and Brücker, 2011). There are considerable differences over regions that are either directed towards international exports or towards the reception of product imports (Dauth et al., 2014). Overall, Baas and Brücker (2011) show that the increase in German exports to the new member countries has been larger than the increase in imports.

Figure 1 depicts aggregated trade flows between Germany and 7 Central and Eastern European Countries (CEE7) that accessed the European Union by 2004: the Czech Republic, Estonia, Latvia, Lithuania, Poland, Slovenia and Slowakia. These new member countries are relevant trade partners for the old member countries of the EU. The figure shows that the import flow from these CEE7 increases with the same trend before and after the date of the Enlargement. Export flows into these countries, in contrast, push to a steeper trend one year after the Enlargement. The break in exports in 2009 is likely to represent the Great Recession, which hit incoming orders of German firms strongest in that specific year.

To gain deeper insights into industry-specific trade patterns, Figure 2 contains trade balance charts for 2-digit manufacturing industries between Germany and the CEE7. Trade balances are defined as exports minus imports. There is a strong increase in the trade balance in the food sector after 2007 that exceeds the level in the 1990's. The tobacco industry has evenly balanced imports and exports, and continues on this trend after the Enlargement. In the clothing industry, clothing trade balance is on an increasing trend, which already started before the Enlargement in 2000. Leather trade and drapery

\footnotetext{
${ }^{1}$ The Czech Republic, Estonia, Latvia, Lithuania, Poland, Slovenia and Slovakia imported goods amounting to 83.5 billion Euro in 2001 (source: Eurostat Comext), while Germany exported 52 billion Euro to these countries (source: Statistisches Bundesamt).
} 
Figure 1: Trade flows between Europe and CEE7 countries

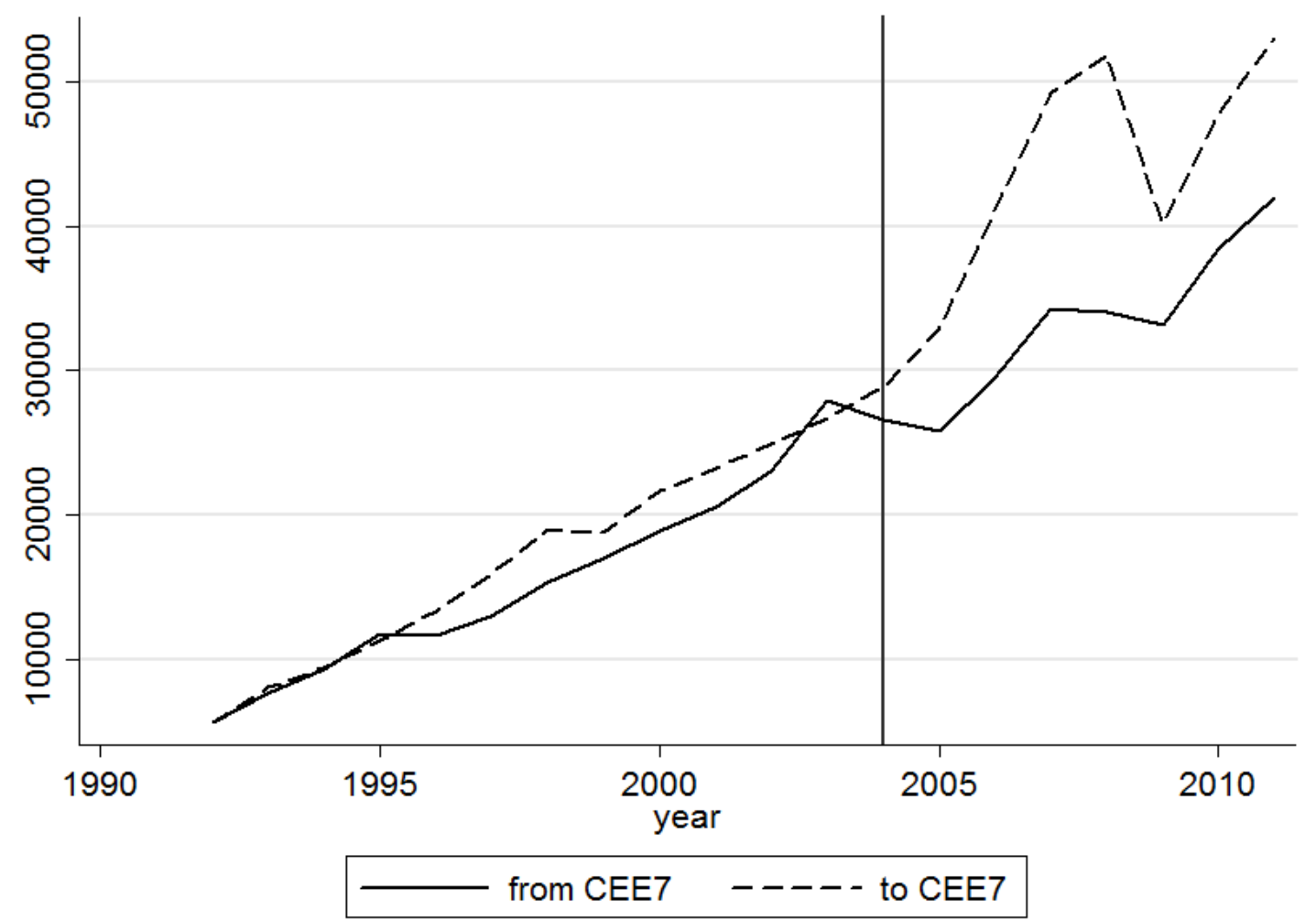

Note: In million Euro; all numbers deflated by export and import price indices, respectively. Source: Comext EU27 Trade Data, Eurostat.

trade, in contrast, unaffectedly remain with their levels. The wood and the paper industry exhibit increasing trade balances from 2003 on, that is one year prior to the Enlargement. The printing industry trade balance is not touched by this trend and slightly decreases. In the chemical industry, there are clear upward trends for coking and petroleum processing starting in 2004. For chemical products, the upward trend already started in 1995, but accelerates after 2005. Metal working and metal production have been on upward trends before the Enlargement as well, and even increase after 2004. In the engineering sector, mechanical engineering peaks after the Enlargement, and returns to its prior level in 2009. The same pattern is true for office machinery. Other mechanical industries - electricity generating machines, broadcasting and communication engineering, medical and measurement technology - do not show trade balance changes associated with the Enlargement. In the automotive sector, the trade balance decreases strongly between 2001 and 2003, and peaks in the following years. In 2009, it reverses to its former trend. These figures indicate strong heterogeneity in the reactions of trade flows to the Enlargement over industries, and suggest that different firms react differently to the potential of the increased market.

This paragraph explains the age and skill mix in Germany and the CEEC. Statistics on the age and skill endowment of workforces in Germany and in the CEEC are shown in Figures 7 and 8 in the Appendix. The age mix of the workforces in the CEEC is similar to 
Figure 2: Trade balance between Germany and CEE7 countries in 2-digit manufacturing industries
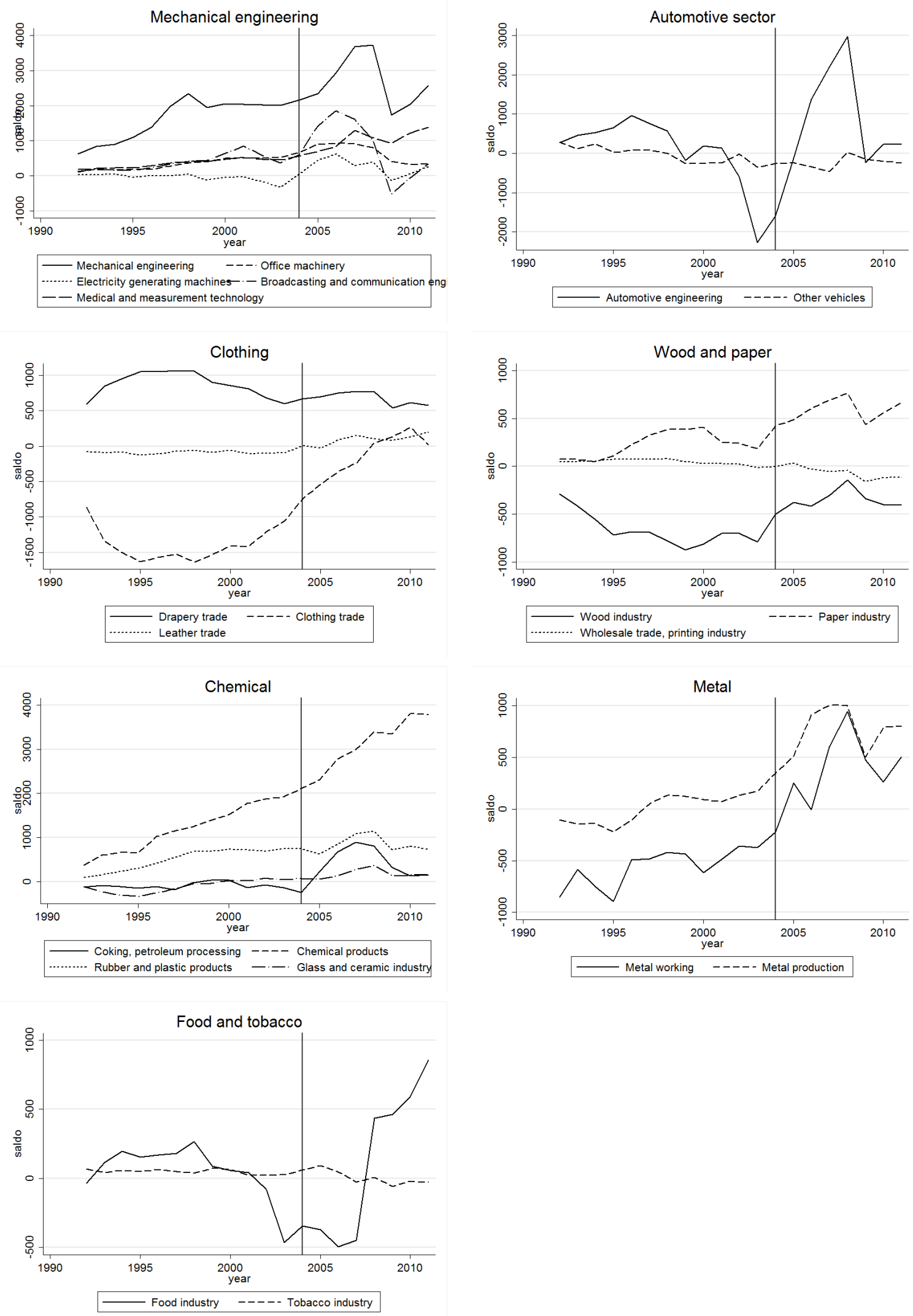

Note: In million Euro; all numbers deflated by export and import price indices, respectively. Source: Comext EU27 Trade Data, Eurostat. 
that in Germany. The share of older workers (50 to 64) is between 19 per cent (Poland) and 26 per cent (Czech Republic), with Germany at the upper end with 25 per cent. Prime-age workers (25 to 49) represent 63 (Latvia) to 70 per cent (Slovenia) of workers in the CEEC, and 63 per cent in Germany. The share of young workers is between 8 and 13 per cent in the CEEC, and 12 per cent in Germany. Similar to Germany, the CEEC exhibit stagnation in fertility and shrinking populations, combined with increasing life expectancy (Stanowsky, 2007). These numbers indicate only small relative abundances of age groups between Germany and the CEEC.

The skill mix of the workforce in the CEEC is more heterogeneous. ${ }^{2}$ The share of low-skilled workers in the CEEC ranges between 7 (Czech Republic) and 15 per cent (Hungary, Slovenia), with a clear gap to Germany at 18 per cent. However, Germany has a relatively low share of medium-skilled workers of 58 per cent compared to the CEEC, who all have higher shares except Estonia. Concerning the share of high-skilled workers, Germany has 24 per cent, where the CEEC range between 14 (Czech Republic) and 30 per cent (Lithuania). The Baltic States have a clear relative abundance of highskilled workers, where other CEEC like the Czech Republic, Poland and Slovakia have an abundance of medium-skilled workers. Germany itself has a high share of low-skilled workers. As Germany has a relative abundance of low-skilled workers, offshoring lowskilled jobs does not seem rewarding according to the theory. But almost all CEEC have a relative abundance of medium-skilled workers compared to Germany, so that relocating medium-skilled jobs from Germany to the CEEC seems reasonable.

Since the mid-1990's, the German manufacturing industry has strongly increased in productivity. Indications for an increase in productivity are decreased unit labour costs and increased real wages in the manufacturing industry, as argued by Dustmann et al. (2014). They state that the productivity of German manufacturing strongly profited from trade opening with the CEEC, much more so than other European countries. Accompanied by the increase in productivity, the German manufacturing sector was shrinking in terms of employment. ${ }^{3}$ Potential effects of the trade opening for the labour market were therefore widely discussed. Export chances for domestic firms are opposed by increased import pressure from abroad.

Based on these considerations, I argue that the 2004 Eastern Enlargement created exogenous variation in trade liberalisation. The fact that the labour market liberalisation was delayed by 7 years rules out supply-side effects to a certain extent. This setting enables me to estimate the effect of the Enlargement on employment outcomes. The following section discusses the literature and derives hypotheses, and argues how the observed increase in trade balances can give rise to relative demand shifts over skill and age groups.

\footnotetext{
${ }^{2}$ The figures in this paragraph are based on the International Standard Classification of Education (ISCED). Low-skilled workers have less than primary, primary and lower secondary education (levels 0-2); medium-skilled workers have upper secondary and post-secondary non-tertiary education (levels 3 and 4); high-skilled workers have a short-cycle tertiary, bachelor or equivalent, master or equivalent and doctoral or equivalent (levels 5-8).

${ }^{3}$ In 1995, 21.6 per cent of all jobs were located in manufacturing, while it was only 17.7 per cent in 2007 (Dustmann et al., 2014).
} 


\section{Theories and hypotheses}

Heckscher-Ohlin-type models expect increased trade with relatively low-skill abundant countries to shift production towards skill-intensive industries in the high-skill abundant country, whereby the relative employment of high-skilled labour increases, and employment of low-skilled labour decreases. This may result in wage and employment gaps between skill groups and contribute to a relative demand shift for labour. Lowering trade barriers with developing countries, which are relatively low-skill abundant, hits low-skilled workers as compared to other skill groups, when domestic firms specialise in skill-intensive production (Wood, 1995).

In recent models, heterogeneous firms within one industry are in competition for productivity, which is strongly correlated with export status. Only productive firms can bear the cost to enter and survive in the export market. An increase in trade opening induces the most productive firms to increase exports and profits (Melitz, 2003). Less productive firms are still able to export, but with decreasing profits, while others can no longer afford to export. The least productive firms leave the market completely. The Melitz model predicts that trade liberalisation reallocates export market shares towards the more productive firms.

The empirical literature names different explanations and channels for the relative demand shift of trade liberalisation. The following sections discuss which factors play a role in the framework of the Eastern Enlargement. Based on this argumentation, I derive hypotheses on how the Enlargement is expected to shift skill- and age-specific labour demand.

\subsection{Skill upgrading}

Trade liberalisation can improve the cost structure of production, and lead to a process of quality competition. In this reallocation process, exporting firms differentiate production of goods with respect to quality, when consumers have a taste-for-quality. To be able to produce these higher-quality goods, they are in need of qualified labour. This theory is lined out by Verhoogen (2008), who describes the concept in a nutshell that "worker quality improves product quality." As workers' skills are imperfect substitutes, firms have to invest in better-qualified workers in order to produce a higher-quality good. In this way, quality upgrading of exporting firms gives rise to skill upgrading, i.e. that more productive workers sort themselves into exporting firms which have a higher demand for skills (Frías et al., 2009). Quality upgrading results in an employment shift from lowskill- towards high-skill-oriented firms within a specific industry. Empirically, Bloom et al. (2012) show that employment in Europe has shifted towards higher-skill-oriented firms as an adaptation to increased import competition with China, while employment in general decreased. For Germany, Kutschka (2011) finds that quality competition indeed decreases the relative demand for low-skilled workers, but accounts only for a small share of the overall decline. 
Picking up the analysis of trade balance between Germany and the CEE7 from Section 2, I assume skill upgrading due to the Enlargement to be prevalent in mechanical engineering as well as the food and paper industries. The increase in trade balances can be attributed to the time period after the Enlargement, so that trade liberalisation is likely to have increased quality competition. Skill upgrading implies a demand shift from lower- towards higher-skilled workers, and is likely to be present in manufacturing firms. A firm that conducts quality upgrading is expected to set up jobs for and increase hirings of high-skilled workers, while separations of low- or medium-skilled workers increase.

\subsection{Outsourcing and offshoring}

Another explanation for a relative demand shift is outsourcing and offshoring of lowskilled jobs (Feenstra and Hanson, 1996, 1997). ${ }^{4}$ Outsourcing denotes the process when the production of intermediate goods is moved abroad, and the intermediate goods are then imported and assembled to the final product. This can lead to cost savings for the firms, thereby increasing their productivity, size, and competitiveness. In this process, the demand for low-skilled workers in the outsourcing firm decreases, and the relative demand for high-skilled workers increases. The CEEC have potential for direct investment and outsourcing from German manufacturing firms, as these countries have a relatively many low- and medium-skilled workers, low wages, and historical ties to Germany and the German language. Furthermore, working regulations are more flexible than in Germany. Geishecker (2004) finds that outsourcing low-skilled jobs has contributed to the shift from low-skilled towards high-skilled workers in German manufacturing. More specifically, Geishecker $(2006,2008)$ shows that German outsourcing to CEEC significantly lowers the domestic demand for and the employment security of low-skilled workers. He argues that the magnitude of this effect is comparable to the effect of skill-biased technological change. Marin (2011) states and empirically demonstrates that German (and Austrian) job losses for the low-skilled due to outsourcing are small. She argues that offshoring of high-skilled jobs arises, as the workforce in CEEC is comparably high skilled. This would reverse the demand shift described by Feenstra and Hanson (1996). Using the estimation approach by Feenstra and Hanson, she finds an absence of relative wage growth for skilled workers in Germany, and an increase in relative wages for skilled workers in Poland.

The literature on offshoring implies a decrease in the demand for low-skilled labour in reaction to the Enlargement, as offshoring predominantly takes place among jobs with low skill requirements. Given the skill mix in Germany and the CEEC as described in Section 2, offshoring of jobs with medium skill requirements seems even more likely. This should increase job destruction especially among medium-skilled workers. When firms increase their profits by these cost savings, new jobs for higher-skilled workers may be created.

\footnotetext{
${ }^{4}$ Blinder (2009) calculates that U.S. occupations that are most prone to offshoring are not low-skilled or low-wage jobs. He states that the correlation between offshorability and education is almost zero.
} 


\subsection{Skill-biased technological change}

Other studies point towards the adoption of better technology and declining computer prices being the reason for the demand shift in skills. Bustos (2011) argues that a tariff reduction between trade partners increases revenues for exporting firms, which then invest in new profitable technologies. Based on the framework by Yeaple (2005), this process of technology-upgrading induces exporting firms to adopt a high-fixed-cost modern technology, which in turn leads to skill upgrading. A related explanation for within-industry skill shifts is that trade can trigger skill-biased technological change (Berman et al., 1998; Autor et al., 2003). The argument is that technological progress within firms favours higher-skilled over lower-skilled workers, as computerisation reduces the demand for lowskilled workers, and makes high-skilled workers even more productive. The relevance of trade-induced technological change is underlined by Bloom et al. (2012) who show that innovation in firms in twelve European countries increased with the pressure of Chinese imports. They observe increased IT intensity and productivity of the firms. This is likely to reflect offshoring of less IT intensive and low productivity parts of the production chain. In addition to this effect on technological change, they find that the trade increase is responsible for employment reallocations towards firms with higher skill concentration.

Many firms undergo profound organisational changes in respond to demand shocks. Typically, hierarchy and organisation are adapted to flatter and more autonomous structures. Organisational change has implications for workers: possessing more autonomy and responsibility, they need higher skills to fulfil their tasks. This raises the question whether organisational change is skill-biased as well, as it is suspected to demand higher-skilled workers to perform the increased complexity of tasks. Caroli and Van Reenen (2001) empirically analyse the relationship between organisational change and skill-specific labour demand of French and British establishments. The central finding is that firms that introduce organisational changes exhibit a falling demand for low-skilled workers. Greenan (2003) and Piva et al. (2005) present evidence that organisational change might be even more relevant for the skill-specific demand shift than technological change as such.

Technological change is also known to shift task-specific demand. As the task content of jobs may differ from their skill content, it is likely that technological change is not limited to shift skill-specific demand. While routine tasks of workers can be subject to substitution by computers or machines, this is not true for manual tasks (as shown by Autor et al., 2003 for the U.S., and by Goos and Manning, 2007 for Britain). Demand moves away from routine tasks towards non-routine manual and non-routine cognitive tasks. Autor and Dorn (2009) point out an age discrepancy in the displacement of routine tasks: the increasing demand for non-routine cognitive tasks is almost only filled with young workers, while the demand for non-routine manual tasks concentrates on older workers. In the analysis of the relationship between the initial share of routine employment in a region and the subsequent employment growth in the German service sector, Senftleben and Wielandt (2012) show that technological change reallocates former routine tasks to non- 
routine manual and non-routine cognitive tasks. Whereas younger workers have better chances to go into cognitive tasks by human capital investments, older workers are more likely to end up in manual tasks. The authors find that for older workers, the decline in routine jobs is accompanied by a similar rise in non-routine manual jobs.

Occupations seem to be the channel through which not only technological change but also offshoring influences wage and employment inequality ("trade in tasks", e.g. Grossman and Rossi-Hansberg, 2008; Firpo et al., 2011). Autor et al. (2013b) show that predominantly routine-intensive jobs are subject to offshoring. Hogrefe (2013) finds that German manufacturing industries reduce domestic demand for routine and non-interactive tasks in response to increased offshoring.

According to trade-induced technological and organisational change, I expect firms that react to the increased market potential of the Enlargement to dismiss low- and mediumskilled workers and to hire higher-skilled workers. My hypothesis is that jobs for lowand/or medium-skilled workers are to be removed (or moved abroad). For high-skilled workers, additional jobs should be created. Technological change that is task-biased is likely to shift the demand for specific age groups of workers. When older workers concentrate in routine jobs which are subject to offshoring, then the relative demand for older workers decreases. This might be reflected by increased domestic job destruction for this age group.

\subsection{Age-biased technological change}

Innovations require workers to adapt to new technologies. In this adaptation process, the skills of older workers tend to lose relevance and drop in their relative value. Moreover, older workers are discriminated with respect to training participation, so their relative employment prospects diminish with technological innovations in the firm (Behaghel and Greenan, 2010). In this way, innovations can be viewed as age-biased against older workers (Behaghel et al., 2014; Beckmann, 2007).

Empirical studies show that innovations decrease employment of older workers (Hujer and Radic, 2006, for Germany) and that new technologies in the firms favour younger workers in hirings as compared to older workers, whereagainst organisational innovations decrease separations for older workers stronger than for younger workers (Aubert et al., 2006, for France). Bartel and Sicherman (1993) find that older workers retire sooner after unexpected technology upgrading, but steady technological change increases the amount of training, and therefore leads to delayed retirement and longer careers of older workers.

As older workers lack the required mobility and the flexibility to update their skills, the demand might be passed on to younger workers, who additionally exhibit lower employment protection and wages (Blossfeld et al., 2005). They are equipped with up-to-date skills and accept more flexible contracts than their older colleagues. The literature on age-specifc differences in job and worker flows (e.g. Abowd et al., 2006, 2007) states that younger workers have higher employment dynamics than older workers. Clark and Sum- 
mers (1981) find that cyclical fluctuations require more dynamics from younger than from older workers. Gielen and van Ours (2006) show that Dutch firms cyclically adjust employment through hirings of younger workers and through separations of older workers. Job creation for younger workers is more sensitive in response to cyclical fluctuations than for older workers. Job destruction, however, does not respond differently across age groups.

The effects of age-biased technological and organisational change are likely to strengthen the age-specific demand shift due to the Enlargement. Consequently, the demand would be passed on to younger workers. For younger workers, the flexibility demand of the increased market is expected to be reflected by higher volatility, i.e. more separations and more accessions.

\section{Data and descriptive facts}

The econometric analysis is based on a German linked employer-employee panel data set, the LIAB. It combines data from the IAB-Establishment Panel and the Employment Statistics Register (see Alda et al., 2005). The IAB-Establishment Panel is based on an annual survey, whose sampling frame encompasses all German establishments that employ at least one employee paying social security contributions. New establishments are added to the survey every year to incorporate births and to correct for panel mortality and exits in order to preserve the panel's representative character. From the establishment level data I gain information on a number of establishment characteristics such as establishment size, the workforce composition as well as collective bargaining coverage. The second data source is the Employment Statistics Register, which is an administrative data set based on reports from employers in compliance with the notifying procedure for the German social security system. The establishment data can be merged with the individual data using a unique establishment identifier. This procedure obliges employers to provide a notification at the beginning and the end of each employment relationship for all employees who are covered by the German social security system. The notifications provide individual information on age, gender, nationality, employment status (blue-/white-collar, part-/fulltime, apprenticeship), educational status, tenure and the gross daily wage. Since there is an upper contribution limit to the social security system, gross daily wages are top-coded. Following Gartner (2005), right-censored observations are replaced by imputed wages. The latter are randomly drawn from a truncated normal distribution whose moments are constructed by the predicted values from Tobit regressions and whose (lower) truncation point is given by the contribution limit to the social security system.

I use the panel waves from 1995 to 2009. The data set allows me to merge the selected establishment data with notifications for all workers that are employed at June 30th of each year. Each establishment in my sample is required to be observed during the years 2003, 2004 and 2005, i.e. around the date of the Enlargement. ${ }^{5}$

\footnotetext{
${ }^{5}$ I define the year 2004 to be after the Enlargement. The data are collected in June 2004, which is one month after the date of the Enlargement.
} 
Measurement of employment changes is based on worker flow rates and on job flow rates at the establishment-year-level. I define worker accessions $W A$ and separations $W S$ for establishment $j$ in year $t$ according to Burgess et al. (2000):

$$
\begin{aligned}
& W A_{j t}=\frac{A_{j t}}{\left(E_{j t}+E_{j, t-1}\right) / 2} \\
& W S_{j t}=\frac{S_{j, t-1}}{\left(E_{j t}+E_{j, t-1}\right) / 2}
\end{aligned}
$$

$A_{j t}$ is the number of accessions, $S_{j t}$ the number of separations, and $E_{j t}$ the stock of employment at establishment $j$ in year $t . \Delta E_{j t}$ takes first differences and represents the annual employment growth. In a similar manner, I calculate job creation $J C$ and job destruction $J D$ in the style of Davis and Haltiwanger (1999):

$$
J C_{j t}=\frac{\Delta E_{j t}}{\left(E_{j t}+E_{j, t-1}\right) / 2}
$$

for all $\Delta E_{j t} \geq 0$.

$$
J D_{j t}=\frac{\left|\Delta E_{j t}\right|}{\left(E_{j t}+E_{j, t-1}\right) / 2}
$$

for all $\Delta E_{j t}<0$. Overall, it holds that

$$
\Delta E_{j t}=J C_{j t}-J D_{j t}=W A_{j t}-W S_{j t}
$$

When I calculate age and skill specific effects, I define age and skill groups in the following way. Workers are considered high-skilled when they hold a college or university degree. They are medium-skilled when they have completed vocational training. Lowskilled are those workers who did not complete vocational training, irrespective of their school degree. Concerning the age groups, I define young workers to be up to 29 years old, prime-age between 30 and 49, and old workers over 50 years.

Table 1 describes the data set at the level of the establishment in averages over 1995 to 2009. In the manufacturing sector, establishments employ 258 workers on average. The yearly worker accession rate is 8 per cent, and the worker separation rate is 8 per cent as well. Job creation and job destruction per year amount to 5 per cent, respectively. Detailed information on the outcome variables in the age and skill groups is contained in Table 5 in the Appendix.

The workers' average age is 42 years: 14 per cent of the workforce is younger than 30 , and 25 per cent is older than 50 . 11 per cent do not have completed vocational training and are considered low-skilled. The majority of 81 per cent is medium-skilled with completed vocational training, and 8 per cent are high-skilled with a university degree or a degree from a technical college. On average, workers earn 76 Euro per day, 24 per cent are female, and 4 per cent do not have German nationality.

The average sales per worker of an establishment is about 160,000 Euro. Establish- 
Table 1: Descriptive statistics at the establishment level

\begin{tabular}{lrr}
\hline \hline & mean & std. dev. \\
\hline Number of employees in establishment & 258.35 & 970.39 \\
Accession rate & 0.08 & 0.12 \\
Separation rate & 0.08 & 0.14 \\
Job creation rate & 0.05 & 0.11 \\
Job destruction rate & 0.05 & 0.13 \\
\hline Age in years & 42.16 & 3.88 \\
Younger than 29 & 0.14 & 0.34 \\
Prime-age & 0.61 & 0.49 \\
Older than 50 & 0.25 & 0.43 \\
Without completed vocational training & 0.11 & 0.31 \\
Completed vocational training & 0.81 & 0.39 \\
University or technical college degree & 0.08 & 0.28 \\
\hline Sales per worker in million Euro & 0.16 & 0.37 \\
Export share & 19.36 & 24.60 \\
Export share to Eastern Europe & 2.19 & 4.60 \\
\hline Daily wage in Euro & 75.83 & 1.41 \\
Female workers & 0.24 & 0.22 \\
Foreign workers & 0.04 & 0.08 \\
White-collar workers & 0.31 & 0.23 \\
Works council & 0.50 & 0.48 \\
\hline Number of establishments & \multicolumn{2}{c}{1,370} \\
Number of observations & \multicolumn{2}{c}{} \\
\hline \hline
\end{tabular}

ments export 19 per cent of their goods, and 2 per cent are exported to Eastern European countries. 50 per cent of the establishments have a works council.

\section{Empirical analysis}

In Section 5.1, the effect of the Eastern Enlargement on changes in the number of workers, worker flows, and job flows on the establishment level is estimated, and Section 5.2 works out the effect heterogeneity across skill and age groups.

\subsection{The effect of the Enlargement on employment changes}

Using the 2004 European Union Eastern Enlargement as a source of exogenous variation in trade liberalisation, I estimate the effect of trade liberalisation on establishment-level employment changes. In a trend-adjusted difference-in-differences approach (DiDiD; compare Blundell and Costa Dias, 2009), I compare outcomes across establishments that are differentially exposed to international trade. Besides the variation over the periods before and after the Enlargement, I use a productivity term to differentiate firms by how strong they are affected, and allow for trend adjustment in the before- and after-period, respectively. 
The approach to utilise firm productivity to approximate the intensity of a tradeinduced demand shock has been suggested by Verhoogen (2008). It is based on the seminal Melitz (2003) model, where heterogeneous firms within one industry are in competition for export shares. Productivity is strongly correlated with the export status of establishments. Only the most productive firms can bear the cost to enter and survive in the export market. An increase in trade openness induces the most productive firms to increase exports and profits. Less productive firms are still able to export, but with decreasing profits. The least productive firms - which operated only domestically - leave the market completely. The model predicts that trade liberalisation reallocates export market shares towards the more productive firms. ${ }^{6}$

Building on this framework, initial firm-level productivity is assumed to be a monotonous representation of the trade-induced demand shock created by the Enlargement. This translates into a treatment intensity term that is continuous in its exposure to product demand. This approach has been taken up by Frías et al. (2009) to analyse the export wage premia effects of the 1994 Mexican Peso devaluation. Based on this idea, I exploit the argument that the direction and magnitude of the trade-induced demand shock of the Enlargement should be driven by initial differences in firm-level productivity. In the following, I use this approach to estimate heterogeneous employment effects of the Enlargement.

The challenge of this approach is to find a suitable proxy for establishment-level productivity. For my empirical model, the treatment intensity term $\pi_{j}$ is specified by initial establishment-level sales divided by the number of workers. Sales per worker are likely to represent the efficiency structure of the establishment, and should be a good proxy for productivity. This choice is supported by Verhoogen (2008) and is based on the consideration that more productive firms are larger in the domestic as well as in the export market. Frías et al. (2009) run a number of robustness checks and find that their results do not depend on the choice of the productivity proxy.

For the period before the Enlargement (1995 to 2003), initial per-worker sales are measured in the first year the establishment is observed. After the Enlargement (2004 to 2009), initial per-worker sales are measured in the calendar year 2004. By taking initial values before and after the Enlargement, I account for productivity changes that may occur due to the trade-induced demand shock. Figure 3 shows the distribution of the productivity term in the periods before and after the Enlargement. The two distributions are very similar. The mass of the distribution is around 25,000 to 175,000 Euro sales per worker. The distribution is skewed to the right, with 99 per cent of firms having less than 500,000 Euro sales per worker. ${ }^{7}$

\footnotetext{
${ }^{6}$ Bernard et al. (1995) analyse U.S. firm panel data and find that manufacturing firms that start exporting strongly increase employment in the short run. However, they find that employment decreases in the long run, since the transition rate out of the exporting market is found to be twice as high as the transition rate into the exporting market. In this way, the current export status does not seem to be a meaningful predictor of long run wage and employment growth.

${ }^{7}$ The remaining 1 per cent of the distribution has values of up to 3.6 million Euro sales per worker. Due to data protection legislation, I am not able to draw the distribution with less than 20 observations
} 
Figure 3: Distribution of sales per worker before and after the Enlargement

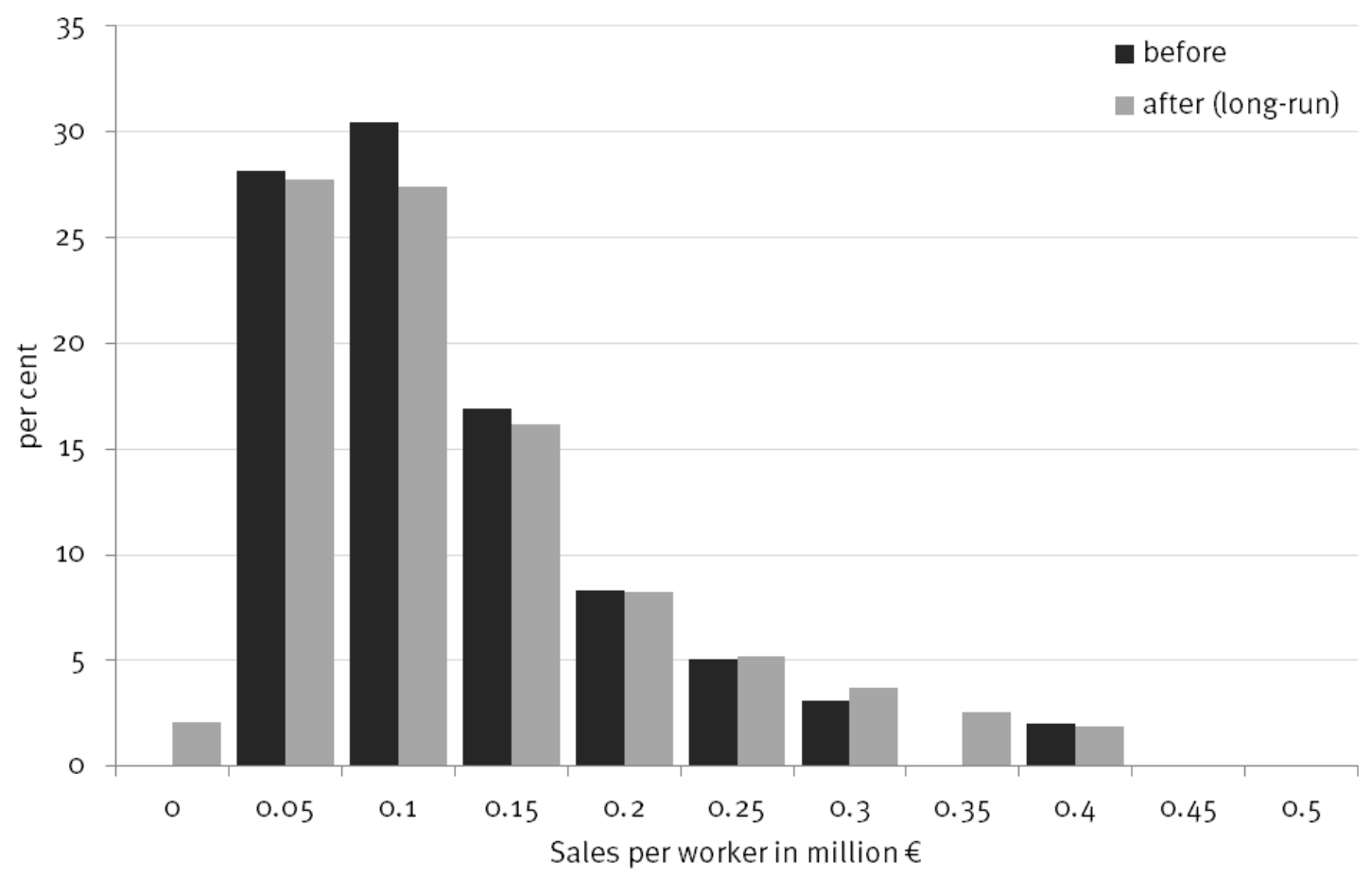

Source: LIAB 1995-2009. Note: Each bar represents classed values of productivity by $+/-0.025$ million Euro. Due to data protection issues, classes with less than 20 observations are not observable.

Figure 4 demonstrates the relation between the productivity term (i.e. sales per worker) and the export share in the period before and after the Enlargement. Highproductivity firms with more than 0.1 million Euro above-average sales per worker clearly increase their exports in the period after the Enlargement. These firms are expected to be affected stronger by the product market opening than establishments with below-average initial productivity.

First-differenced outcome variables $\Delta y_{j}$ to assess employment effects are changes in establishment-level employment $(\Delta E)$, in worker accession and separation rates $(\Delta W A$ and $\Delta W S$ ), as well as in job creation and job destruction rates $(\Delta J C$ and $\Delta J D)$. To demonstrate the relation between the productivity term and the outcome variables, Figure 5.1 shows a nonparametric regression of the employment change on sales per worker. The outcome variable and initial per-worker sales are deviated from industry-year-region averages in order to correct for differences inherent to industry- and region-specific patterns as well as time effects. The deviated nonparametric regression should reflect the same relationship between the outcome and productivity that I will investigate further down with the linear regression model. The graph depicts the relation between annual employment growth on the establishment level and initial per-worker sales. The dashed grey line is the relation in the period before, the solid grey line after the Enlargement.

in one class. 
Figure 4: Nonparametric regression of export share on initial sales per worker 3

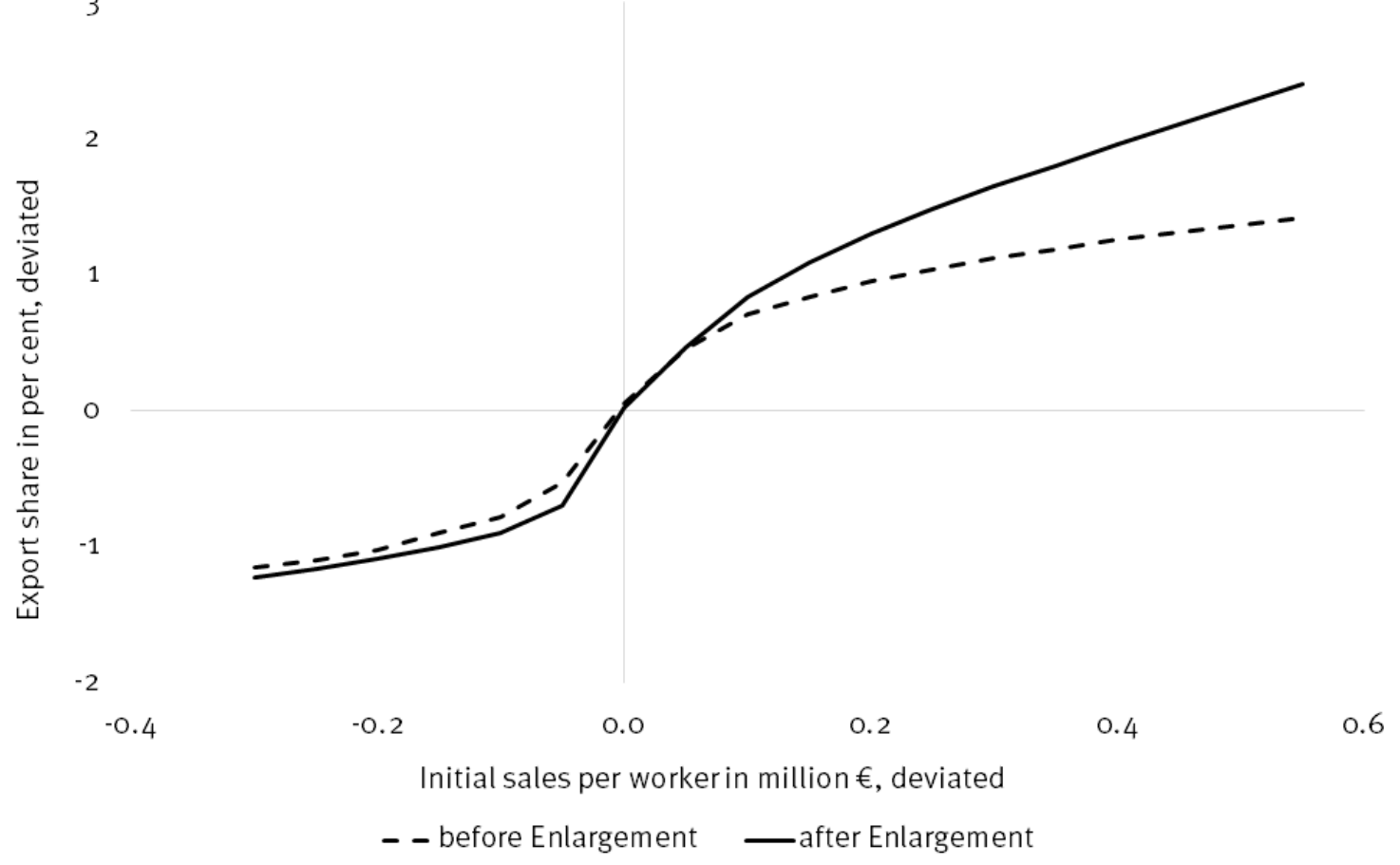

Note: Nonparametric estimations are based on locally weighted least-squares regressions. The smoothing bandwidth is set to 0.8. Due to data protection issues, information on a class with less than 20 observations is not available. Export share and sales per worker are deviated from industry-year-region averages. Sales per worker are represented by initial values in the before and after period, respectively.

Before the Enlargement, employment growth increases in establishments in the upper part of the productivity distribution, and decreases in establishments with low productivity. After the Enlargement, this relation changes in the upper part of the productivity distribution, where yearly employment growth is negative. As a result, the solid black line depicts the difference between the after- and the before-relation of employment growth and productivity. The difference in employment growth, which I interpret as the effect of the Enlargement, is negatively related to productivity, i.e. high-productivity firms experience negative employment growth, whereas low-productivity firms experience positive employment growth.

Figure 6 contains nonparametric regressions of worker flows and job flows on initial perworker sales. The upper panels show changes in the worker accession rate and the worker separation rate in relation to productivity. Accession rates above the average productivity slightly increase after the Enlargement, but remain close to zero. In establishments with below-average productivity, accessions rather decrease. The worker separation rate in establishments with above-average productivity increases considerably, with a positive relation to more productive firms.

The lower panels in Figure 6 show the relation between changes in the job creation 
Figure 5: Nonparametric regressions of employment growth on initial sales per worker

15

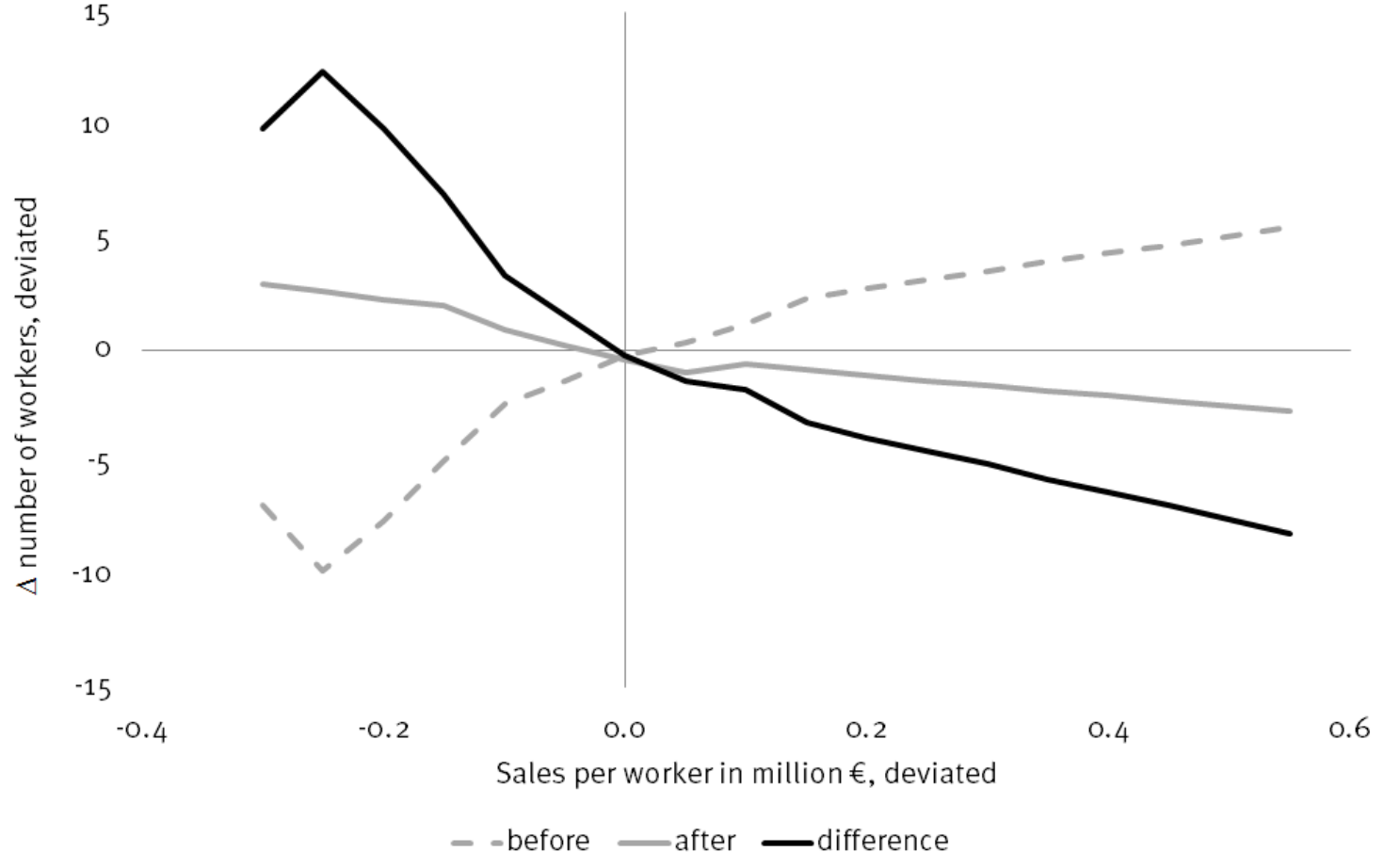

Note: Nonparametric estimation based on locally weighted least-squares regressions. The smoothing bandwidth is set to 0.8. Due to data protection issues, information on a class with less than 20 observations is not available. Employment change and sales per worker are deviated from industry-year-region averages. Sales per worker are represented by initial values in the before and after period, respectively.

and the job destruction rate to productivity. The picture is very similar to the worker flow rates. The difference in job creation rates (solid black line) is almost zero; it is even closer to zero than the worker accession rate. The difference in job destruction rates is positively related to productivity. From the nonparametric graphical analysis, I infer a negative relation between the Enlargement and overall employment growth, and a positive relation between the Enlargement and worker accession and job destruction rates. There is also a positive relation between the Enlargement and worker accession and job creation, but only for firms with below-average productivity.

In the following, I turn to parametric linear regressions and estimate this equation on the level of establishments:

$$
\Delta y_{j t}=\alpha+\beta \pi_{j}+\gamma_{s} D_{s}+\delta_{r} D_{r}+u_{j t}
$$

where $D_{s}$ and $D_{r}$ denote sector and region dummies. First-differenced outcomes $\Delta y_{j}$ and the productivity term $\pi_{j}$ are deviated from their year averages. The equation is estimated separately for the period before (1995 to 2003) and after the Enlargement (2004 to 2009). Moreover, the estimator adjusts for potentially different time trends across the pre- and post-periods (DiDiD; compare Blundell and Costa Dias, 2009). 
Figure 6: Nonparametric regressions of changes in worker flows and job flows on initial sales per worker

$\Delta$ worker accession rate

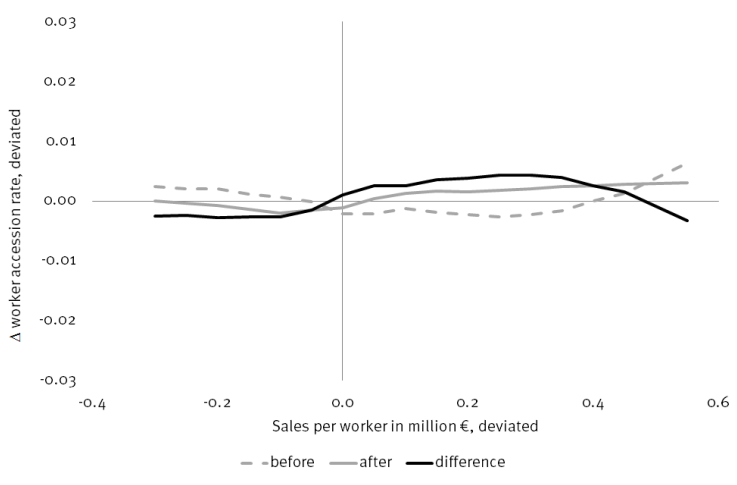

$\Delta$ job creation rate

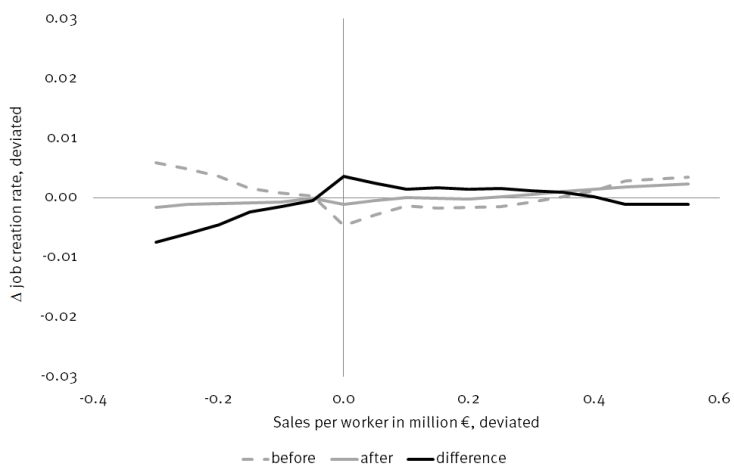

$\Delta$ worker separation rate

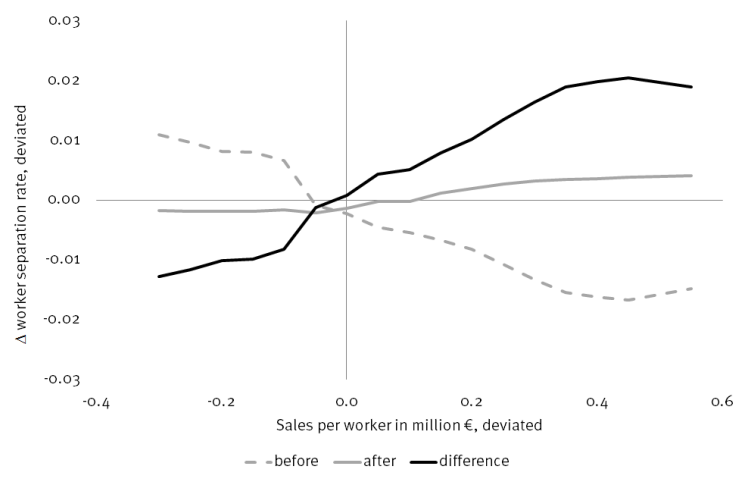

$\Delta$ job destruction rate

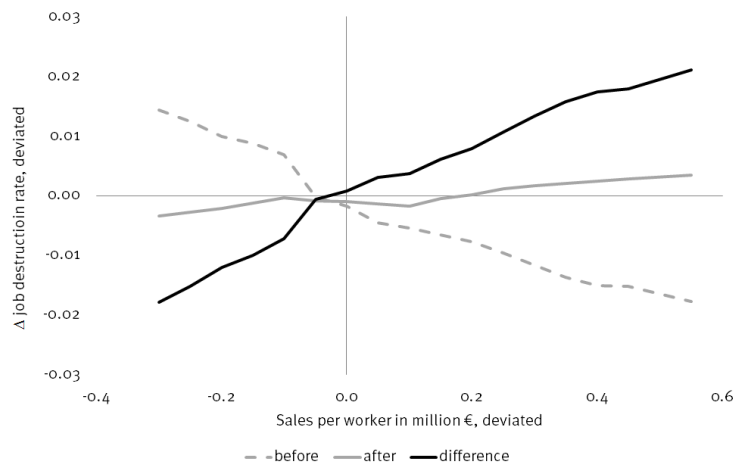

Note: Nonparametric estimations are based on locally weighted least-squares regressions. The smoothing bandwidth is set to 0.8 . Due to data protection issues, information on a class with less than 20 observations is not available. All outcome variables and sales per worker are deviated from industry-year-region averages. Sales per worker are represented by initial values in the before and after period, respectively.

Table 2 presents estimates of employment outcomes on initial productivity before and after the Enlargement, and the difference between these. Before the Enlargement, more productive firms had a positive yearly employment growth $(+7$ workers for firms with +1 million Euro per-worker sales). In the period after the Enlargement, the effect turns negative (-8 workers). The Enlargement had a negative net effect on yearly employment growth in high productivity firms: a firm with +1 million Euro per-worker sales has an average yearly employment growth of -15 workers in consequence to the Enlargement. This effect is highly significant. The effect size gives this net effect in standard deviation units of the outcome variable. So, the Enlargement decreases employment growth by 0.26 standard deviations.

On average, the Enlargement increased the first-differenced worker accession rate by 2 percentage points, which is statistically insignificant. There is a significant positive effect of 7 percentage points on the worker separation rate ( 0.37 standard deviations). For job flows, the Enlargement increased the job creation rate by 1 percentage point; this effect is insignificant. There is a highly significant positive effect of 6 percentage points on the 
Table 2: Effect of the Enlargement on employment outcomes

\begin{tabular}{llccc}
\hline \hline & $\begin{array}{c}\text { Before } \\
(1)\end{array}$ & $\begin{array}{c}\text { After } \\
(2)\end{array}$ & $\begin{array}{c}\text { Net effect } \\
(3)\end{array}$ & $\begin{array}{c}\text { Effect size } \\
(4)\end{array}$ \\
\hline$\Delta E$ & $7.007^{* *}$ & $-8.151^{* * *}$ & $-15.159^{* * *}$ & -0.2591 \\
& $(3.162)$ & $(2.760)$ & $(3.715)$ & \\
$\Delta W A$ & -0.014 & 0.007 & 0.020 & 0.123 \\
& $(0.014)$ & $(0.005)$ & $(0.015)$ & \\
$\Delta W S$ & $-0.057^{* * *}$ & $0.013^{* * *}$ & $0.070^{* * *}$ & 0.370 \\
& $(0.016)$ & $(0.005)$ & $(0.018)$ & \\
$\Delta J C$ & -0.007 & 0.003 & 0.010 & 0.064 \\
& $(0.013)$ & $(0.003)$ & $(0.014)$ & \\
$\Delta J D$ & $-0.050^{* * *}$ & $0.009^{*}$ & $0.059^{* * *}$ & 0.341 \\
& $(0.012)$ & $(0.006)$ & $(0.015)$ & \\
\hline \hline
\end{tabular}

Note: Standard errors in parentheses; clustered at the level of the establishment. Effect size calculated as the difference in standard deviations of the outcome variable. ${ }^{* * *}$ p-value $<0.01,{ }^{* *}$ pvalue $<0.05,{ }^{*}$ p-value $<0.1$.

job destruction rate (0.34 standard deviations). The difference between worker accessions and separations is negative, so overall employment in response to the Enlargement is decreasing. This finding is confirmed by the negative difference between job creation and job destruction.

\subsection{Age- and skill-specific employment effects}

The aim of this section is to analyse the effect heterogeneity of the Eastern Enlargement on employment outcomes. Based on the estimator described in Section 5.1, I investigate the heterogeneity in the effect of the Enlargement over age and skill groups within establishments. To be more specific, I show how the effect differs for high-skilled, medium-skilled and low-skilled workers, and analyse the pattern for young, prime-age and old workers. The estimations are run separately for age and skill groups $g$ to identify the heterogeneous effect of the Enlargement $\beta_{g}$ :

$$
\Delta y_{j t g}=\alpha_{g}+\beta_{g} \pi_{j g}+\gamma_{s g} D_{s g}+\delta_{r g} D_{r g}+u_{j t g} .
$$

Starting with heterogeneous effects of the Enlargement over skill groups, Table 3 presents skill-specific effects on employment growth, worker flows, and job flows. Column (1) in the table shows the net effects of the productivity term before and after the Enlargement; that is the effect of the Enlargement within the specific skill group. Note that the outcome variables have different distributions over the skill groups. Therefore, Column (2) presents the normalised size of the effect, that is the net effect of the Enlargement relative to the standard deviation of the outcome variable. This normalisation allows me to compare the specific effects over the different skill groups. Column (3) obtains the dif- 
ferences between the effect size of the low-skilled or the high-skilled group and the effect size in the medium-skilled group.

An additional +1 million Euro sales per worker significantly reduces the yearly employment growth among medium- and high-skilled workers in consequence of the Enlargement by 10 and 2.5 workers, which are 0.22 and 0.19 standard deviations, and insignificantly by 2.4 workers or 0.07 standard deviations among low-skilled workers. For low-skilled workers, the decline in employment growth is with 0.15 standard deviations significantly smaller than the effect for medium-skilled workers.

Table 3: Skill-specific employment effects

\begin{tabular}{|c|c|c|c|c|}
\hline & & $(1)$ & $(2)$ & (3) \\
\hline & & Net effect & Effect size & Diff.from med \\
\hline & low & -2.415 & -0.0683 & $0.147^{* *}$ \\
\hline & & $(2.089)$ & & $(0.070)$ \\
\hline$\Delta E$ & med & $-9.960^{* * *}$ & -0.216 & \\
\hline$\Delta$ & & $(2.622)$ & & \\
\hline & high & $-2.466^{* * *}$ & -0.189 & 0.027 \\
\hline & & $(0.912)$ & & $(0.079)$ \\
\hline & low & -0.033 & -0.164 & $-0.353^{*}$ \\
\hline & & $(0.040)$ & & $(0.213)$ \\
\hline$\Delta W A$ & med & $0.033^{* *}$ & 0.190 & \\
\hline & & $(0.016)$ & & \\
\hline & high & -0.001 & -0.006 & -0.196 \\
\hline & & $(0.023)$ & & $(0.139)$ \\
\hline & low & $0.055^{*}$ & 0.231 & -0.144 \\
\hline & & $(0.027)$ & & $(0.129)$ \\
\hline$\triangle W S$ & med & $0.072^{* * *}$ & 0.375 & \\
\hline$\Delta V D$ & & $(0.020)$ & & \\
\hline & high & -0.007 & -0.032 & $-0.407^{* * *}$ \\
\hline & & $(0.022)$ & & $(0.127)$ \\
\hline & low & -0.051 & -0.251 & $-0.392^{*}$ \\
\hline & & $(0.037)$ & & $(0.228)$ \\
\hline A $I C$ & med & 0.018 & 0.112 & \\
\hline$\Delta \pi$ & & $(0.014)$ & & \\
\hline & high & 0.008 & 0.038 & -0.074 \\
\hline & & $(0.022)$ & & $(0.136)$ \\
\hline & low & $0.038^{*}$ & 0.170 & -0.157 \\
\hline & & $(0.023)$ & & $(0.115)$ \\
\hline D & med & $0.057^{* * *}$ & 0.326 & \\
\hline$\Delta J$ & & $(0.016)$ & & \\
\hline & high & 0.002 & 0.011 & $-0.315^{* * *}$ \\
\hline & & $(0.016)$ & & $(0.107)$ \\
\hline
\end{tabular}

Note: Standard errors in parentheses; clustered at the level of the establishment. Effect size in column (2) calculated as the difference in standard deviations of the outcome variable. ${ }^{* * *} \mathrm{p}$ value $<0.01,{ }^{* *}$ p-value $<0.05,{ }^{*}$ p-value $<0.1$. 
Turning to changes in worker flows, accession growth increases significantly among medium-skilled workers by 0.19 standard deviations. The negative effect on worker accessions for low-skilled workers is significantly lower than the effect for medium-skilled workers. For high-skilled workers, the effect is -0.01 standard deviations and insignificant. On worker separation growth, the effect is positive and significant for low- and medium-skilled workers with a 0.23 and 0.38 standard deviations increase, respectively. For high-skilled workers, the effect is close to zero and insignificant, but has a negative sign. It is significantly different from the effect for medium-skilled workers.

Changes in job flows are affected in a similar way. The Enlargement reduces job creation growth of the low-skilled by 0.25 standard deviations. Although this estimate is not significant, it is significantly lower than the effect on medium-skilled workers. Effects for medium- and high-skilled workers are positive but insignificant. Regarding job destruction growth, the effects have a positive sign for all skill groups, and are significant for low-skilled (0.17 standard deviations) and medium-skilled workers (0.33 standard deviations). The effect on job destruction for high-skilled workers is almost 0 and insignificant, and significantly larger than the effect for medium-skilled workers.

These estimates indicate that the negative employment effect of the Enlargement is more severe for low- and medium-skilled workers, at it increases their separation rates and job destruction, while high-skilled workers are not affected. This can be interpreted as a sjukk bias in the effect of the Enlargement that is directed against low- and medium-skilled workers.

Table 4 presents the age-specific effects of the Enlargement on growth of employment, job flows, and worker flows. The effect of sales per worker on employment growth in consequence of the Enlargement is negative for all age groups, where the overall effect is driven by prime-age workers. For the prime-age and old workers, the effects are statistically significant with a magnitude of -0.25 and -0.19 standard deviations.

There is no significant effect on the change in worker accessions in any age group. On separations, the significant effects are 0.40 standard deviations for young workers, and 0.24 standard deviations for prime-age workers. The effect for older workers is also quite large with 0.17 standard deviations, but insignificant. 
Table 4: Age-specific employment effects

\begin{tabular}{|c|c|c|c|c|}
\hline & & (1) & $(2)$ & (3) \\
\hline & & Net effect & Effect size & Diff.from prime \\
\hline & young & -1.353 & -0.076 & 0.175 \\
\hline & & $(1.595)$ & & $(0.135)$ \\
\hline$\Delta E$ & prime & $\begin{array}{l}-9.045^{* * *} \\
(3.006)\end{array}$ & -0.251 & \\
\hline & old & $-4.637^{* * *}$ & -0.191 & 0.060 \\
\hline & & $(1.644)$ & & $(0.117)$ \\
\hline & young & -0.014 & -0.040 & -0.076 \\
\hline & & $(0.039)$ & & $(0.124)$ \\
\hline$\Delta W A$ & prime & 0.007 & 0.036 & \\
\hline$\Delta W A$ & & $(0.015)$ & & \\
\hline & old & 0.012 & 0.052 & 0.016 \\
\hline & & $(0.025)$ & & $(0.134)$ \\
\hline & young & $0.134^{* * *}$ & 0.400 & 0.159 \\
\hline & & $(0.037)$ & & $(0.144)$ \\
\hline$\Delta W S$ & prime & $0.049^{* *}$ & 0.241 & \\
\hline & & $(0.021)$ & & \\
\hline & old & 0.039 & 0.174 & -0.067 \\
\hline & & $(0.026)$ & & $(0.129)$ \\
\hline & young & -0.025 & -0.087 & -0.101 \\
\hline & & $(0.032)$ & & $(0.132)$ \\
\hline$\triangle I C$ & prime & 0.002 & 0.015 & \\
\hline$\Delta \pi$ & & $(0.016)$ & & \\
\hline & old & 0.022 & 0.102 & 0.088 \\
\hline & & $(0.026)$ & & $(0.152)$ \\
\hline & young & $0.124^{* * *}$ & 0.438 & 0.201 \\
\hline & & $(0.034)$ & & $(0.144)$ \\
\hline$\Delta I D$ & prime & $0.044^{* *}$ & 0.237 & \\
\hline & & $(0.018)$ & & \\
\hline & old & $0.049^{* * *}$ & 0.265 & 0.029 \\
\hline & & $(0.018)$ & & $(0.118)$ \\
\hline
\end{tabular}

Note: Standard errors in parentheses; clustered at the level of the establishment. Effect size in column (3) calculated as the difference in standard deviations of the outcome variable. ${ }^{* * *} \mathrm{p}$ value $<0.01,{ }^{* *}$ p-value $<0.05,{ }^{*}$ p-value $<0.1$.

The estimates on job flows mirror the estimates on worker flows. Job creation growth is not significantly affected in all age groups. Effects on job destruction growth are thereagainst highly significant in all age groups. The Enlargement increases job destruction by 0.44 standard deviations for young workers, and by 0.24 and 0.27 standard deviations for prime-age and old workers, respectively. The effect for young workers is significantly larger than the effect for prime-age workers.

The age-specific employment effects of the Enlargement indicate decreased employment growth among prime-age and older workers, but increased separations and job destruction 
among young and prime-age workers. These numbers do not suggest a clear age bias in the effect of the Enlargement.

\subsection{Robustness checks}

The evidence from the nonparametric regressions in Figure 6 suggests that the slope of the relation between some outcome variables and initial productivity changes at the origin. In the following estimations, I allow the effect of $\pi_{j}$ to change at 0 , i.e. I estimate the relation:

$$
\Delta y_{j t}=\alpha+\beta^{-} \pi_{j}^{-}+\beta^{+} \pi_{j}^{+}+\gamma_{s} D_{s}+\delta_{r} D_{r}+u_{j t},
$$

where $\pi_{j}^{-}=I(\pi<0) \cdot \pi_{j}$ and $\pi_{j}^{+}=I(\pi>0) \cdot \pi_{j}$. The estimation results are shown in Table 6 in the Appendix to this Chapter, where I further test whether $\beta^{-}=\beta^{+}$, i.e. whether the specification in Equation 6 is justified. The coefficients and their statistical significance indicate that the employment growth effects are driven by establishments with above-average levels of initial per-worker sales $\left(\pi^{+}\right)$, although $\beta^{+}$and $\beta^{-}$are not significantly different from each other. Effects on worker accession rates tend to be larger for below-average performing establishments, where some coefficients turn significant. The negative effect on worker separations is driven by below-average performing establishments in the before-period, and by above-average performing establishments in the after-period. The net effect is stronger for below-average establishments, which is significantly larger than the above-average effect at a 10 per cent level. Concerning job creation rates, none of the effects are statistically significant, although coefficients for below-average performing establishments are larger than coefficients for above-average performing establishments. In the period before the Enlargement, the effect on job destruction is much stronger for belowaverage performing establishments. In the period after the Enlargement, the signs change between both groups, and in the difference between both periods, the effect is stronger for below-average performing establishments. However, considering the net effects of both periods, $\beta^{-}$and $\beta^{+}$are not significantly different. I conclude that in the periods before and after the Enlargement, some of the effects differ between establishments with belowor above-average values of initial sales per worker. But the differences between the net effects for positive and negative deviations (Column 3) are statistically negligible. The specification in Equation 6 seems justified.

In addition, one might be concerned about the measurement of sales. For the baseline estimates in Table 2, I use sales in the year the establishment is first observed in the panel data set. However, there might be cyclical variation in sales' initial values over the before period from 1995 to 2003. The starting value for the after period in 2004 might be an exceptionally high or low value as compared to the years after. To test whether the choice of initial values influences my empirical analysis, I alter the sampling of sales. So, I refrain from taking initial values and instead average yearly sales over the beforeperiod and over the after-period, respectively. The results of the estimations based on 
this averaged version of sales per worker can be found in Table 7 in the Appendix. The effect on employment growth per establishment is smaller, but still significant. The effect on worker accessions remains with the same sign and insignificant. But for job creation, the estimate turns negative, though still insignificant. For worker separations and job destruction, the direction, magnitude and significance of the effects do not change at all. My estimates do not seem to be driven by the choice of the initial values of sales per worker.

To test the robustness of my estimates with respect to the choice of the productivity proxy, the estimations are also run with different productivity proxy variables. Table 8 in the Appendix runs the regression in Equation 6 with value added as a productivity proxy. This robustness check is inspired by Müller (2012), who argues that value added might represent an establishment's economic performance in a more appropriate way than sales due to different structures of intermediate inputs in the production process. The estimates confirm the overall picture that the effect on employment growth is negative (though insignificant in this specification), and on worker separations and job destruction positive (and significant). However, using value added, the positive effect on changes in worker accessions turns positive, though on a 10 per cent level only. Again, value added seems to be a relevant proxy for productivity, but not exactly in the same way as sales.

The next productivity proxies are inspired by Frías et al. (2009) and use binary indicator variables whether the establishments export and whether the establishments export to Eastern Europe. ${ }^{8}$ The estimates of the robustness regressions are shown in Tables 9 and 10 in the Appendix to this chapter. The effects on employment growth in Column (3) are smaller and insignificant with the export dummy or the dummy for exports to Eastern Europe as productivity indicators. The effects on changes in worker separation and job destruction have the same sign and are significant as well, though with a smaller magnitude than the regressions with sales per worker. Different to sales per worker, the effect on job creation turns negative (but remains insignificant). The effects on job destruction become smaller, but remain significant. Overall, the export indicators seem to differentiate firms with regard to their underlying productivity in a similar way as sales per worker do. However, the effects become smaller in their magnitude and employment growth even becomes insignificant. In my empirical model, exports do not seem to be a perfect substitute for sales to proxy the underlying productivity distribution. ${ }^{9}$

Moreover, I perform a robustness check to analyse the presence of an anticipation effect. As the Enlargement has been announced already in December 2002, it may be that

\footnotetext{
8 "Eastern Europe" is not defined by the survey, i.e. I do not know which destination countries the establishment considers to belong to "Eastern Europe". Moreover, as exports to Eastern Europe have not been surveyed before 2003, the starting values for the before-period are taken from the year 2003.

${ }^{9}$ I shortly summarise the results of the robustness check on the sensitivity of the choice of the productivity proxy. For skill-specific effects, all effects that are significant with sales per worker keep their sign when switching to the export indicators. There is, however, one exception: The effect on worker accessions for the low-skilled, which is significantly negative in my main specification, changes to insignificant positive when switching to the export indicators. For age-specific effects, all statistically significant coefficients have the same sign when I switch to the export dummy or the export dummy for Eastern Europe as productivity proxies.
} 
German firms have adjusted employment prior to the actual accession. Therefore, I estimate Equation 6 with altered before and after periods. The period before the expected anticipation is set to 1995 to 2002, where the period after the anticipation is set to 2003 to 2009. The anticipation effect on employment growth is negative, but insignificant (see Table 11). The effects on worker accessions and job creation are negative, but insignificant. For worker separations and job destruction, the effects are significantly positive, but smaller than the actual effects of the Enlargement. This permits the interpretation that an anticipation effect is present and would imply that establishments have already increased separations and job destruction in anticipation of the Enlargement. In consequence, the effects in Table 2 are likely to underestimate the overall effect of the Enlargement.

\section{Conclusion}

The aim of this analysis is to provide evidence on a potential age and a skill bias in the employment effect of trade liberalisation. I focused on the 2004 EU Eastern Enlargement to estimate the effect of the actual opening of the borders between the new member countries and Germany. I used information on the development of manufacturing firms in the periods before and after the Enlargement, and constructed a productivity variable to approximate the intensity of the market opening. With a DiDiD estimator, I found a negative effect of the Enlargement on employment growth, which is channelled by increased worker separation and increased job destruction. This result is in contrast to the study by Braakmann and Vogel (2011), who find no employment effects, and to Brülhart et al. (2012), who find positive employment effects. These studies, however, estimate the effect of the Enlargement for regions that are located close to the opening border in comparison to regions that are farther from it. The result stands also in contrast to the study by Dauth et al. (2014), who estimate the effect of increased trade with Eastern Europe and China on regional manufacturing employment growth and find negative effects for regions with increased import exposure, and positive effects for regions with increased export exposure. My estimates are, on the contrary, based on variation over establishmentlevel productivity, and indicate that more productive firms - that are more involved in exporting - have reduced employment growth in reaction to the Enlargement.

Based on this estimator, I separately estimated the employment effects of the Enlargement in three skill groups and in three age groups. I found that employment growth dropped in all skill groups. Low- and medium-skilled workers suffered increased separations and increased job destruction, and the effects are stronger for low-skilled workers. Moreover, the low-skilled have significantly reduced accessions as compared to mediumskilled workers. I find no effects on worker flows and job flows for the high-skilled. These findings give rise to a skill bias in the employment effect of the Enlargement that is directed against low- and medium-skilled workers. The increase in separations is likely to reflect skill upgrading, while the increased job destruction among low-and medium-skilled workers is more in favour of the hypothesis of offshoring. The bias can be explained by the 
fact that the CEEC are relatively low- and medium-skill abundant and exhibit lower wage levels. Thus, it seems that after the Enlargement they attracted offshoring in the low- and medium-skill segment. The skill-specific results contradict Braakmann and Vogel (2011), who do not find a differential effect on the share of low-skilled workers in establishments. They do not consider effects on the shares of medium- or high-skilled workers.

The employment growth effect of the Enlargement is negative for prime-age and older workers. Both groups experienced increased job destruction, and so did the young workers. Separations have significantly increased for young and prime-age workers only. I found no significant effects on worker accessions, although the coefficient has a negative sign for young and a positive sign for old workers, and is close to zero for prime-age workers. These results do not indicate a clear age bias. While employment drops strongest for prime-age and older workers, younger workers experienced high worker separation and job destruction. These estimates are not in line with my hypothesis that the trade-induced technological change favours younger over older workers. In consequence to the 2004 Eastern Enlargement to the European Union, these results to not confirm an age bias in the employment effects of the trade-induced demand shock. 


\section{References}

Abowd, J. M., Haltiwanger, J., Lane, J., McKinney, K. L., and Sandusky, K. (2007). Technology and the demand for skill: An analysis of within and between firm differences. IZA Discussion Paper No. 2707.

Abowd, J. M., Kramarz, F., and Roux, S. (2006). Wages, mobility and firm performance: Advantages and insights from using matched worker-firm data. Economic Journal, 116(512):F245-F285.

Alda, H., Bender, S., and Gartner, H. (2005). The linked employer-employee dataset created from the IAB establishment panel and the process-produced data of the IAB (LIAB). Schmollers Jahrbuch, 125:327-336.

Aubert, P., Caroli, E., and Roger, M. (2006). New technologies, organisation and age: Firm-level evidence. Economic Journal, 116:F73-F93.

Autor, D. and Dorn, D. (2009). This job is 'getting old:' measuring changes in job opportunities using occupational age structure. American Economic Review, 99(2):4551.

Autor, D., Dorn, D., and Hanson, G. H. (2013a). The China syndrome: Local labor market effects of import competition in the United States. American Economic Review, 103(6):2121-2168.

Autor, D., Dorn, D., and Hanson, G. H. (2013b). Untangling trade and technology: Evidence from local labor markets. Unpublished Manuscript.

Autor, D., Dorn, D., Hanson, G. H., and Song, J. (2013c). Trade adjustment: Worker level evidence. Mimeo.

Autor, D., Levy, F., and Murnane, R. J. (2003). The skill content of recent technological change: An empirical explanation. Quarterly Journal of Economics, 118(4):1279-1333.

Baas, T. and Brücker, H. (2011). EU Eastern Enlargement: The benefits from integration and free labour movement. CESifo DICE Report 2.

Bartel, A. P. and Sicherman, N. (1993). Technological change and retirement decisions of older workers. Journal of Labor Economics, 11(1):62-83.

Beckmann, M. (2007). Age-biased technological and organizational change: Firm-level evidence and management implications. WWZ Discussion Paper 03/07, Basel.

Behaghel, L., Caroli, E., and Roger, M. (2014). Age biased technical and organisational change, training and employment prospects of older workers. Economica, forthcoming:368-389. 
Behaghel, L. and Greenan, N. (2010). Training and age-biased technical change. Annales d'Economie et de Statistique, 99-100:317-342.

Berman, E., Bound, J., and Machin, S. (1998). Implications of skill-biased technological change: International evidence. Quarterly Journal of Economics, 113(4):1245-1279.

Bernard, A. B., Jensen, J. B., and Lawrence, R. Z. (1995). Exporters, jobs, and wages in U.S. manufacturing: 1976-1987. Brookings Papers on Economic Activity. Microeconomics, 1995:67-11.

Blinder, A. S. (2009). How many US jobs might be offshorable? World Economics, 10(2):41-78.

Bloom, N., Draca, M., and Reenen, J. V. (2012). Trade induced technical change? the impact of Chinese imports on innovation, IT and productivity. NBER Working Paper No. 16717.

Blossfeld, H.-P., Klijzing, E., Mills, M., and Kurz, K., editors (2005). Globalization, uncertainty and youth in society. Routledge, London.

Blundell, R. and Costa Dias, M. (2009). Alternative approaches to evaluation in empirical microeconomics. Journal of Human Resources, 44(3):565-640.

Boeri, T. and Brücker, H. (2001). Eastern Enlargement and EU-Labour Markets: Perceptions, challenges and opportunities. World Economics, 2(1).

Braakmann, N. and Vogel, A. (2010). The impact of the EU enlargement on the performance of service enterprises in Germany's Eastern border region. Review of World Economcis, 146:75,89.

Braakmann, N. and Vogel, A. (2011). How does economic integration influence employment and wages in border regions? the case of the EU enlargement 2004 and Germany's eastern border. Review of World Economcis, 147:303-323.

Brülhart, M., Carrère, C., and Trionfetti, F. (2012). How wages and employment adjust to trade liberalization: Quasi-experimental evidence from Austria. Journal of International Economics, 86:68-81.

Burgess, S., Lane, J., and Stevens, D. (2000). Job flows, worker flows, and churning. Journal of Labor Economics, 18:473-502.

Bustos, P. (2011). Trade liberalization, exports, and technology upgrading: Evidence on the impact of MERCOSUR on Argentinian firms. American Economic Review, 101(1):304-340.

Caroli, E. and Van Reenen, J. (2001). Skill-biased organizational change? evidence from a panel of British And French establishments. Quarterly Journal of Economics, 116(4):1449-1492. 
Clark, K. B. and Summers, L. H. (1981). Demographic differences in cyclical employment variation. Journal of Human Re, 16(1):61-79.

Dauth, W., Findeisen, S., and Suedekum, J. (2014). The rise of the East and the Far East: German labor markets and trade integration. Journal of the European Economic Association, forthcoming.

Davis, S. J. and Haltiwanger, J. (1999). Gross job flows. In Ashenfelter, O. and Card, D., editors, Handbook of Labor Economics, pages 2711-2805.

Dustmann, C., Fitzenberger, B., Schönberg, U., and Spitz-Oener, A. (2014). From sick man of Europe to economic superstar: Germany's resurgent economy. Journal of Economic Perspectives, 28(1):167-188.

Egger, H. and Kreickemeier, U. (2009). Firm heterogeneity and the labour market effects of trade liberalisation. International Economic Review, 50:187-216.

Feenstra, R. C. and Hanson, G. H. (1996). Foreign investment, outsourcing and relative wages. In Feenstra, R., Grossman, G., and Irwin, D., editors, Political Economy of Trade Policy: Essays in Honor of Jagdish Bhagwati, pages 89-172, Cambridge. MIT.

Feenstra, R. C. and Hanson, G. H. (1997). Foreign direct investment and relative wages: Evidence from Mexico's maquiladoras. Journal of International Economics, 42:371-393.

Firpo, S., Fortin, N. M., and Lemieux, T. (2011). Occupational tasks and changes in the wage structure. IZA Discussion Paper No. 5542, Bonn.

Frías, J. A., Kaplan, D. S., and Verhoogen, E. A. (2009). Exports and wage premia: Evidence from Mexican employer-employee data. Unpublished Manuscript.

Gartner, H. (2005). The imputation of wages above the contribution limit with the German IAB employment sample. FDZ-Methodenreport 02/2005, Nürnberg.

Geishecker, I. (2004). Outsourcing and the relative demand for low-skilled labour: Exemplary evidence from German manufacturing industries. In Meulders, D. E., Plasman, R., and Rycx, F., editors, Minimum Wages, Low Pay and Unemployment, pages 176-194, New York. Palgrave Macmillan.

Geishecker, I. (2006). Does outsourcing to Central and Eastern Europe really threaten manual workers' jobs in Germany? The World Economy, 29(5):559-583.

Geishecker, I. (2008). The impact of international outsourcing on individual employment security: A micro-level analysis. Labour Economics, 15(3):291-314.

Gielen, A. C. and van Ours, J. C. (2006). Age-specific cyclical effects in job reallocation and labor mobility. Labour Economics, 13(4):493-504. 
Goos, M. and Manning, A. (2007). Lousy jobs and lovely jobs: The rising polarization of work in Britain. Review of Economics and Statistics, 89(1):118-133.

Greenan, N. (2003). Organisational change, technology, employment and skills: An empirical study of French manufacturing. Cambridge Journal of Economics, 27(2):287-316.

Grossman, G. M. and Rossi-Hansberg, E. (2008). Trading tasks: A simple theory of offshoring. American Economic Review, 98(5):1978-97.

Helpman, E., Itskhoki, O., and Redding, S. (2010). Inequality and unemployment in a global economy. Econometrica, 78(4):1239-1283.

Hogrefe, J. (2013). Offshoring and relative labor demand from a task perspective. ZEW Discussion Paper No. 13-067, Mannheim.

Hornok, C. (2010). Trade-enhancing EU Enlargement and the resurgence of east-east trade. Focus on European Economic Integration, 3:79-94.

Hujer, R. and Radic, D. (2006). Age and skill biased technological change: A multiple treatment approach using a linked employer employee data set. Unpublished Manuscript.

Hummels, D. (2007). Transportation costs and international trade in the second era of globalization. Journal of Economic Perspectives, 21(3):131-154.

Katz, L. F. and Autor, D. H. (1999). Changes in the wage structure and earnings inequality. In Ashenfelter, O. and Card, D., editors, Handbook of Labor Economics, volume 3, pages $1463-1555$.

Kutschka, E. (2011). Quality upgrading, skill demand and international trade: The case of German manufacturing. FEMM Working Paper No. 22/2011, University of Magdeburg.

Marin, D. (2011). The opening up of Eastern Europe at 20: Jobs, skills, and 'reverse maquiladoras'. In Jovanovic, M., editor, Handbook of International Economics, volume 2. Edward Elgar.

Melitz, M. J. (2003). The impact of trade on intra-industry reallocation and aggregate industry productivity. Econometrica, 71:1695-1725.

Müller, S. (2012). Works councils and establishment productivity. Industrial and Labor Relations Review, 65(4):880-898.

Piva, M., Santarelli, E., and Vivarelli, M. (2005). The skill bias effect of technological and organisational change: Evidence and policy implications. Research Policy, 34(2):141157.

Senftleben, C. and Wielandt, H. (2012). The polarization of employment in German local labor markets. SFB 649 discussion paper, No. 2012-013. 
Skirbekk, V. (2008). Age and productivity capacity: Descriptions, causes and policy options. Ageing Horizons, 8:4-12.

Slaughter, M. J. (1998). International trade and labour market outcomes: Results, questions, and policy options. Economic Journal, 108:1452-1462.

Stanowsky, J. (2007). Central and eastern European demographics - that shrinking feeling! Allianz Dresdner Economic Research Working Paper No. 88.

Verhoogen, E. A. (2008). Trade, quality upgrading, and wage inequality in the Mexican manufacturing sector. Quarterly Journal of Economics, 123(2):489-530.

Wood, A. (1995). How trade hurt unskilled workers. Journal of Economic Perspectives, $9(3): 57-80$.

Yeaple, S. R. (2005). A simple model of firm heterogeneity, international trade, and wages. Journal of International Economics, 65(1):1-20. 


\section{Appendix}

Figure 7: Age mix of the workforces in Germany and the CEEC

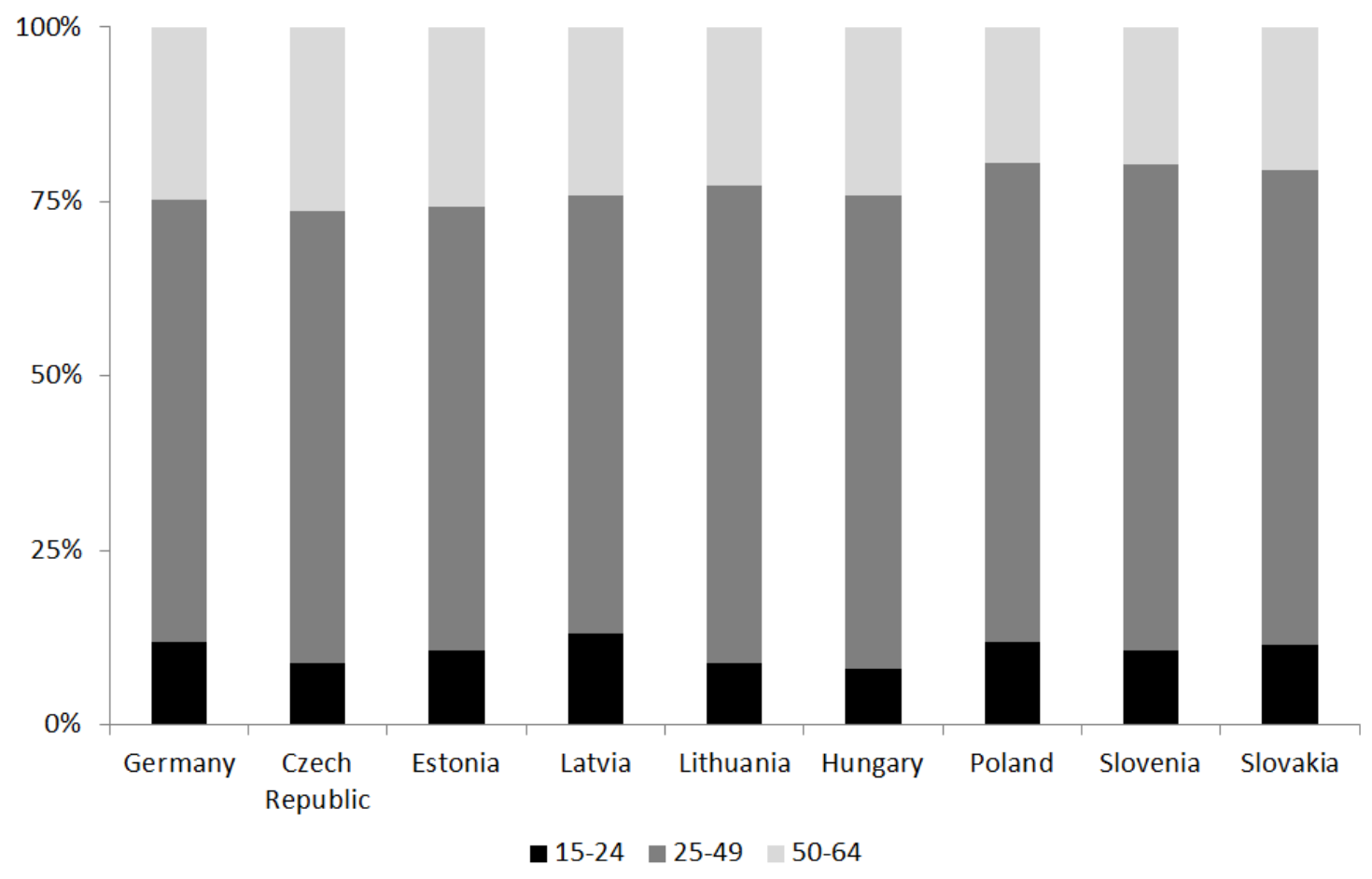

Source: Eurostat; own computations.

Figure 8: Skill mix of the workforces in Germany and the CEEC

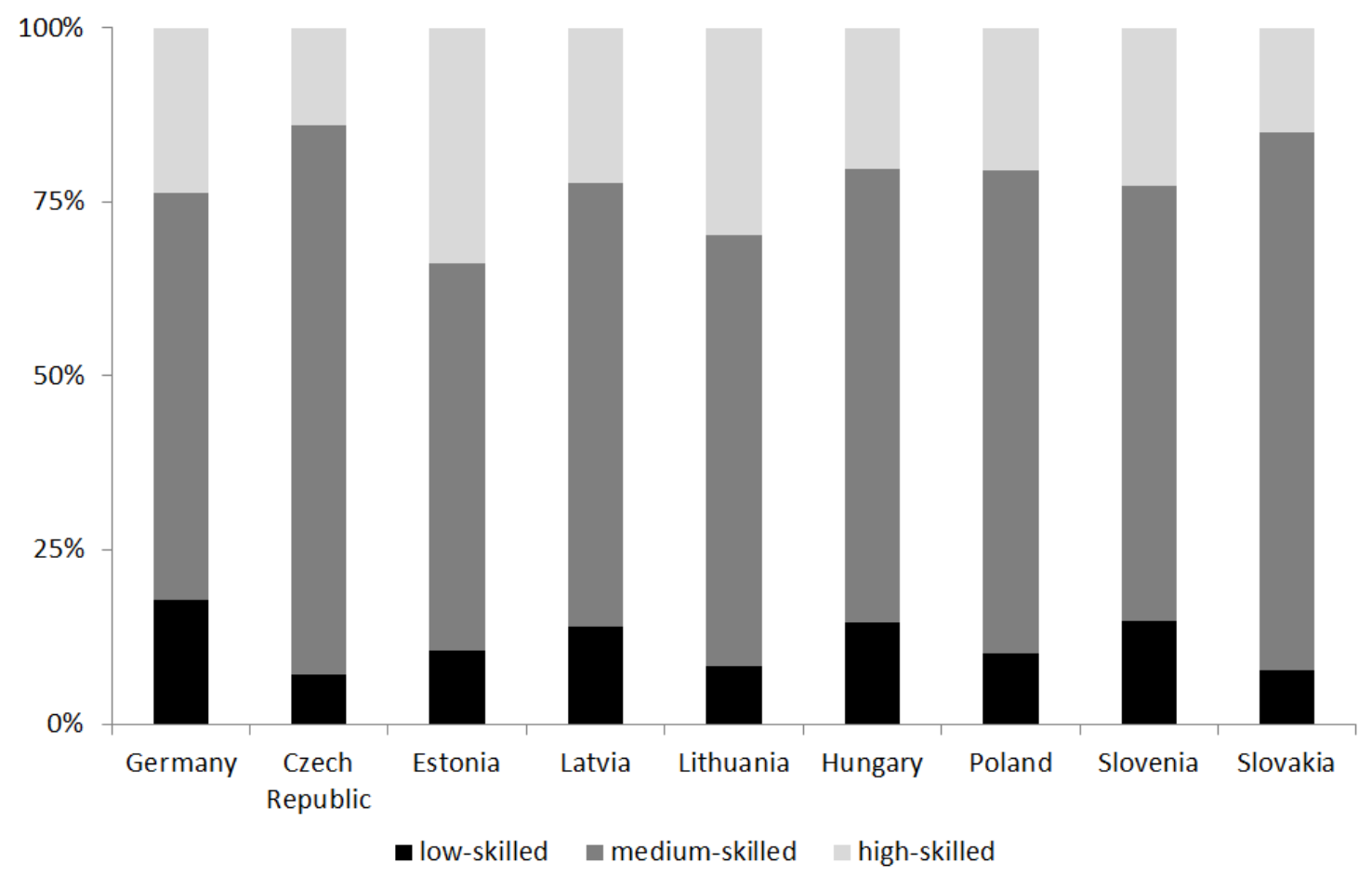

Source: Eurostat; own computations. 
Table 5: Outcome variables in averages over 1995 to 2009

\begin{tabular}{|c|c|c|c|c|c|}
\hline outcome & group & level & std. dev. & first diff. & std. dev. \\
\hline \multirow{7}{*}{ number of workers } & overall & 258.3512 & 970.3922 & -2.1756 & 58.5161 \\
\hline & low & 63.8464 & 188.5017 & -2.8433 & 35.3754 \\
\hline & med & 186.6717 & 693.6061 & -0.9880 & 46.1703 \\
\hline & high & 51.9598 & 214.2104 & 0.8496 & 13.0657 \\
\hline & young & 39.6344 & 141.8807 & -1.5198 & 17.8297 \\
\hline & prime & 167.5864 & 638.7125 & -2.3027 & 36.0185 \\
\hline & old & 69.5821 & 235.8700 & 1.47662 & 24.2785 \\
\hline \multirow{7}{*}{ worker accession rate } & overall & 0.0847 & 0.1237 & -0.0060 & 0.1634 \\
\hline & low & 0.0657 & 0.1530 & -0.0082 & 0.3407 \\
\hline & med & 0.0859 & 0.1302 & -0.0060 & 0.1713 \\
\hline & high & 0.0963 & 0.1632 & -0.0055 & 0.2196 \\
\hline & young & 0.2175 & 0.2458 & -0.0118 & 0.3407 \\
\hline & prime & 0.0977 & 0.1370 & -0.0083 & 0.1830 \\
\hline & old & 0.1523 & 0.1679 & -0.0066 & 0.2296 \\
\hline \multirow{7}{*}{ worker separation rate } & overall & 0.0841 & 0.1423 & 0.0169 & 0.1881 \\
\hline & low & 0.0892 & 0.1721 & 0.0158 & 0.2397 \\
\hline & med & 0.0819 & 0.1425 & 0.0168 & 0.1921 \\
\hline & high & 0.0751 & 0.1524 & 0.0145 & 0.2114 \\
\hline & young & 0.2282 & 0.2425 & 0.0157 & 0.3362 \\
\hline & prime & 0.1121 & 0.1503 & 0.0154 & 0.2015 \\
\hline & old & 0.1035 & 0.1627 & 0.0203 & 0.2230 \\
\hline \multirow{7}{*}{ job creation rate } & overall & 0.0477 & 0.1115 & -0.0111 & 0.1481 \\
\hline & low & 0.0424 & 0.1368 & -0.0100 & 0.2833 \\
\hline & med & 0.0505 & 0.1176 & -0.0108 & 0.1604 \\
\hline & high & 0.0645 & 0.1483 & -0.0099 & 0.1978 \\
\hline & young & 0.1010 & 0.2051 & -0.0127 & 0.2833 \\
\hline & prime & 0.0472 & 0.1205 & -0.0111 & 0.1604 \\
\hline & old & 0.0931 & 0.1595 & -0.0167 & 0.2117 \\
\hline \multirow{7}{*}{ job destruction rate } & overall & 0.0471 & 0.1315 & 0.0118 & 0.1729 \\
\hline & low & 0.0659 & 0.1595 & 0.0140 & 0.2235 \\
\hline & med & 0.0464 & 0.1300 & 0.0119 & 0.1747 \\
\hline & high & 0.0433 & 0.1338 & 0.0101 & 0.1842 \\
\hline & young & 0.1116 & 0.2108 & 0.0148 & 0.2823 \\
\hline & prime & 0.0616 & 0.1396 & 0.0126 & 0.1871 \\
\hline & old & 0.0442 & 0.1339 & 0.0103 & 0.1828 \\
\hline
\end{tabular}

Note: The average numbers of workers in the skill and age groups do not add up to the overall number of workers, as workers can change their skill level or age into the next age group. 
Table 6: Effect of the Enlargement on employment outcomes for establishments with below- and above-average initial per-worker sales

\begin{tabular}{|c|c|c|c|c|}
\hline $\begin{array}{l}\text { Outcome } \\
\text { variable }\end{array}$ & $\begin{array}{c}\text { Explanatory } \\
\text { variable }\end{array}$ & $\begin{array}{c}\text { Before } \\
\text { (1) }\end{array}$ & $\begin{array}{c}\text { After } \\
(2)\end{array}$ & $\begin{array}{c}\text { Net effect } \\
(3)\end{array}$ \\
\hline \multirow{6}{*}{$\Delta E$} & $\pi^{+}$ & $7.975^{* *}$ & $-8.795^{* * *}$ & $-16.771^{* * *}$ \\
\hline & & $(4.056)$ & $(2.848)$ & $(4.439)$ \\
\hline & $\pi^{-}$ & -5.828 & -0.733 & 5.095 \\
\hline & & $(17.269)$ & $(24.968)$ & $(29.744)$ \\
\hline & Difference & 13.804 & -8.062 & -21.866 \\
\hline & & $(18.886)$ & $(26.255)$ & $(31.657)$ \\
\hline \multirow{6}{*}{$\Delta W A$} & $\pi^{+}$ & -0.001 & 0.023 & 0.004 \\
\hline & & $(0.013)$ & $(0.023)$ & $(0.014)$ \\
\hline & $\pi^{-}$ & -0.051 & $0.051^{* *}$ & $0.102^{*}$ \\
\hline & & $(0.047)$ & $(0.023)$ & $(0.059)$ \\
\hline & Difference & 0.050 & $-0.048^{* *}$ & -0.098 \\
\hline & & $(0.051)$ & $(0.023)$ & $(0.062)$ \\
\hline \multirow{6}{*}{$\Delta W S$} & $\pi^{+}$ & -0.022 & $0.015^{* * *}$ & $0.037^{* *}$ \\
\hline & & $(0.015)$ & $(0.004)$ & $(0.015)$ \\
\hline & $\pi^{-}$ & $-0.165^{* * *}$ & -0.010 & $0.155^{* * *}$ \\
\hline & & $(0.047)$ & $(0.023)$ & $(0.058)$ \\
\hline & Difference & $0.143^{* * *}$ & 0.025 & $0.118^{*}$ \\
\hline & & $(0.050)$ & $(0.023)$ & $(0.060)$ \\
\hline \multirow{6}{*}{$\Delta J C$} & $\pi^{+}$ & -0.005 & 0.000 & 0.006 \\
\hline & & $(0.013)$ & $(0.002)$ & $(0.013)$ \\
\hline & $\pi^{-}$ & -0.011 & 0.032 & 0.043 \\
\hline & & $(0.044)$ & $(0.020)$ & $(0.054)$ \\
\hline & Difference & 0.005 & -0.032 & -0.038 \\
\hline & & $(0.048)$ & $(0.021)$ & $(0.058)$ \\
\hline \multirow{6}{*}{$\Delta J D$} & $\pi^{+}$ & $-0.026^{* *}$ & $0.013^{* * *}$ & $0.038^{* * *}$ \\
\hline & & $(0.011)$ & $(0.004)$ & $(0.012)$ \\
\hline & $\pi^{-}$ & $-0.124^{* * *}$ & -0.029 & $0.096^{*}$ \\
\hline & & $(0.037)$ & $(0.023)$ & $(0.050)$ \\
\hline & Difference & $0.099^{* *}$ & $0.041^{*}$ & -0.058 \\
\hline & & $(0.040)$ & $(0.023)$ & $(0.051)$ \\
\hline
\end{tabular}

Note: Standard errors in parentheses; clustered at the level of the establishment. ${ }^{* * *}$ p-value $<0.01$, ${ }^{* *}$ p-value $<0.05,{ }^{*}$ p-value $<0.1$. 
Table 7: Robustness check: Sales per worker averaged in periods before and after the Enlargement

\begin{tabular}{lcccc}
\hline \hline & $\begin{array}{c}\text { Before } \\
(1)\end{array}$ & $\begin{array}{c}\text { After } \\
(2)\end{array}$ & $\begin{array}{c}\text { Net effect } \\
(3)\end{array}$ & $\begin{array}{c}\text { Effect size } \\
(4)\end{array}$ \\
\hline$\Delta E$ & $4.274^{*}$ & -6.308 & $-10.582^{* *}$ & -0.181 \\
& $(2.455)$ & $(3.954)$ & $(4.464)$ & \\
$\Delta W A$ & 0.001 & 0.008 & 0.006 & 0.039 \\
& $(0.011)$ & $(0.005)$ & $(0.013)$ & \\
$\Delta W S$ & $-0.056^{* * *}$ & $0.010^{* *}$ & $0.067^{* * *}$ & 0.355 \\
& $(0.012)$ & $(0.005)$ & $(0.014)$ & \\
$\Delta J C$ & 0.014 & 0.004 & -0.010 & -0.065 \\
& $(0.010)$ & $(0.004)$ & $(0.011)$ & \\
$\Delta J D$ & $-0.044^{* * *}$ & 0.007 & $0.051^{* * *}$ & 0.294 \\
& $(0.009)$ & $(0.006)$ & $(0.012)$ & \\
\hline \hline
\end{tabular}

Note: All outcome variables are first-differenced. Standard errors in parentheses; clustered at the level of the establishment. Effect size calculated as the difference in standard deviations of the outcome variable.

Table 8: Robustness check: Value added as treatment intensity

\begin{tabular}{llccl}
\hline \hline & Before & After & Net effect & Effect size \\
\hline$\Delta E$ & -4.752 & -9.513 & -9.513 & -0.163 \\
& $(17.344)$ & $(12.736)$ & $(21.479)$ & \\
$\Delta W A$ & -0.035 & $0.026^{*}$ & $0.061^{*}$ & 0.374 \\
& $(0.028)$ & $(0.014)$ & $(0.034)$ & \\
$\Delta W S$ & $-0.111^{* * *}$ & 0.011 & $0.122^{* * *}$ & 0.647 \\
& $(0.028)$ & $(0.022)$ & $(0.040)$ & \\
$\Delta J C$ & -0.015 & 0.017 & 0.031 & 0.211 \\
& $(0.027)$ & $(0.014)$ & $(0.033)$ & \\
$\Delta J D$ & $-0.091^{* * *}$ & 0.001 & $0.092^{* *}$ & 0.531 \\
& $(0.025)$ & $(0.021)$ & $(0.037)$ & \\
\hline \hline
\end{tabular}

Note: All outcome variables are first-differenced. Standard errors in parentheses; clustered at the level of the establishment. Effect size calculated as the difference in standard deviations of the outcome variable. 
Table 9: Robustness check: Export indicator as treatment intensity

\begin{tabular}{lcccc}
\hline \hline & $\begin{array}{c}\text { Before } \\
(1)\end{array}$ & $\begin{array}{c}\text { After } \\
(2)\end{array}$ & $\begin{array}{c}\text { Net effect } \\
(3)\end{array}$ & $\begin{array}{c}\text { Effect size } \\
(4)\end{array}$ \\
\hline$\Delta E$ & 1.700 & -1.556 & -3.256 & -0.0556 \\
& $(1.811)$ & $(1.417)$ & $(2.250)$ & \\
$\Delta W A$ & 0.001 & $0.005^{* *}$ & 0.005 & 0.027 \\
& $(0.005)$ & $(0.003)$ & $(0.006)$ & \\
$\Delta W S$ & $-0.023^{* * *}$ & 0.004 & $0.027^{* * *}$ & 0.141 \\
& $(0.005)$ & $(0.003)$ & $(0.007)$ & \\
$\Delta J C$ & $0.009^{*}$ & $0.004^{*}$ & -0.005 & -0.032 \\
& $(0.005)$ & $(0.002)$ & $(0.006)$ & \\
$\Delta J D$ & $-0.015^{* * *}$ & 0.0014 & $0.016^{* * *}$ & 0.094 \\
& $(0.004)$ & $(0.003)$ & $(0.006)$ & \\
\hline \hline
\end{tabular}

Note: All outcome variables are first-differenced. Standard errors in parentheses; clustered at the level of the establishment. Effect size calculated as the difference in standard deviations of the outcome variable.

Table 10: Robustness check: Export indicator Eastern Europe as treatment intensity

\begin{tabular}{llccc}
\hline \hline & $\begin{array}{c}\text { Before } \\
(1)\end{array}$ & $\begin{array}{c}\text { After } \\
(2)\end{array}$ & $\begin{array}{c}\text { Difference } \\
(3)\end{array}$ & $\begin{array}{c}\text { Effect size } \\
(4)\end{array}$ \\
\hline$\Delta E$ & 1.791 & -3.214 & -5.004 & -0.086 \\
& $(2.261)$ & $(2.411)$ & $(3.335)$ & \\
$\Delta W A$ & -0.002 & 0.003 & 0.005 & 0.028 \\
& $(0.005)$ & $(0.002)$ & $(0.006)$ & \\
$\Delta W S$ & $-0.017^{* * *}$ & 0.004 & $0.021^{* * *}$ & 0.111 \\
& $(0.004)$ & $(0.004)$ & $(0.006)$ & \\
$\Delta J C$ & 0.004 & 0.002 & -0.002 & -0.013 \\
& $(0.004)$ & $(0.002)$ & $(0.005)$ & \\
$\Delta J D$ & $-0.012^{* * *}$ & 0.003 & $0.014^{* *}$ & 0.083 \\
& $(0.004)$ & $(0.004)$ & $(0.006)$ & \\
\hline \hline
\end{tabular}

Note: All outcome variables are first-differenced. Standard errors in parentheses; clustered at the level of the establishment. Effect size calculated as the difference in standard deviations of the outcome variable. 
Table 11: Robustness check: Anticipation effects one year prior to the Enlargement

\begin{tabular}{lcccl}
\hline \hline & Before & After & Net effect & Effect size \\
\hline$\Delta E$ & 9.679 & $-3.731^{* *}$ & -13.410 & -0.229 \\
& $(9.771)$ & $(1.626)$ & $(9.877)$ & \\
$\Delta W A$ & 0.020 & 0.003 & -0.016 & -0.098 \\
& $(0.017)$ & $(0.003)$ & $(0.017)$ & \\
$\Delta W S$ & $-0.030^{*}$ & 0.011 & $0.041^{* *}$ & 0.218 \\
& $(0.015)$ & $(0.008)$ & $(0.018)$ & \\
$\Delta J C$ & 0.026 & 0.003 & -0.024 & -0.162 \\
& $(0.018)$ & $(0.002)$ & $(0.018)$ & \\
$\Delta J D$ & $-0.024^{*}$ & 0.010 & $0.033^{* *}$ & 0.191 \\
& $(0.013)$ & $(0.008)$ & $(0.016)$ & \\
\hline \hline
\end{tabular}

Note: All outcome variables are first-differenced. Standard errors in parentheses; clustered at the level of the establishment. Effect size calculated as the difference in standard deviations of the outcome variable. 